Article

\title{
Synthesis and Characterization of $\mathrm{Fe}-\mathrm{TiO}_{2}$ Nanomaterial: Performance Evaluation for RB5 Decolorization and In Vitro Antibacterial Studies
}

\author{
Muhammad Saqib Khan ${ }^{1}{ }^{\oplus}$, Jehanzeb Ali Shah ${ }^{1}$, Nadia Riaz ${ }^{1}{ }^{\circledR}$, Tayyab Ashfaq Butt ${ }^{2}{ }^{\circledR}$, Asim Jahangir Khan ${ }^{1}$, \\ Walid Khalifa ${ }^{2}$, Hatem Hassin Gasmi ${ }^{2}$, Enamur Rahim Latifee ${ }^{2}$, Muhammad Arshad ${ }^{3}$,
} Ahmed Abdullah Alawi Al-Naghi ${ }^{2}$, Anwar Ul-Hamid ${ }^{4} \mathbb{D}$, Muhammad Arshad ${ }^{5, * \mathbb{D}}$ and Muhammad Bilal ${ }^{1, *(\mathbb{D})}$

1 Department of Environmental Sciences, Abbottabad Campus, COMSATS University Islamabad, Abbottabad 22060, Pakistan; muhammadsaqib@yahoo.com (M.S.K.); jehanzeb360@yahoo.com (J.A.S.); nadiariazz@gmail.com (N.R.), asimjkw@gmail.com (A.J.K.)

2 Department of Civil Engineering, University of Hail, Hail 55476, Saudi Arabia; ta.butt@uoh.edu.sa (T.A.B.); w.khalifa@uoh.edu.sa (W.K.); h.gasmi@uoh.edu.sa (H.H.G.); E.Latifee@uoh.edu.sa (E.R.L.); a.alnaghi@uoh.edu.sa (A.A.A.A.-N.)

3 National Center for Physics, Nanosciences and Technology Department, Quaid-i-Azam University Islamabad Campus, Islamabad 44000, Pakistan; Arshad_pr2002@yahoo.com

4 Centre for Engineering Research, King Fahd University of Petroleum and Minerals, Dhahran 31261, Saudi Arabia; anwar@kfupm.edu.sa

5 Institute of Environmental Sciences and Engineering, School of Civil and Environmental Engineering, National University of Sciences and Technology, Islamabad 44000, Pakistan

check for updates

Citation: Khan, M.S.; Shah, J.A.; Riaz, N.; Butt, T.A.; Khan, A.J.; Khalifa, W.; Gasmi, H.H.; Latifee, E.R.; Arshad, M.; Al-Naghi, A.A.A.; et al. Synthesis and Characterization of $\mathrm{Fe}-\mathrm{TiO}_{2}$ Nanomaterial: Performance Evaluation for RB5 Decolorization and In Vitro Antibacterial Studies. Nanomaterials 2021, 11, 436. https:// doi.org/10.3390/nano11020436

Academic Editor: Yiannis Deligiannakis Received: 27 January 2021

Accepted: 3 February 2021

Published: 9 February 2021

Publisher's Note: MDPI stays neutral with regard to jurisdictional claims in published maps and institutional affiliations.

Copyright: (c) 2021 by the authors. Licensee MDPI, Basel, Switzerland. This article is an open access article distributed under the terms and conditions of the Creative Commons Attribution (CC BY) license (https:// creativecommons.org/licenses/by/ $4.0 /)$.
* Correspondence: marshad@iese.nust.edu.pk (M.A.); mbilal@cuiatd.edu.pk (M.B.)

\begin{abstract}
A photocatalytic system for decolorization of double azo reactive black 5 (RB5) dye and water disinfection of E. coli was developed. Sol gel method was employed for the synthesis of $\mathrm{Fe}-\mathrm{TiO}_{2}$ photocatalysts and were characterized using thermogravimetric analysis (TGA), Fourier transform infrared spectroscopy (FTIR), X-ray diffraction (XRD), scanning electron microscopy (SEM) coupled with energy dispersive X-ray analysis (EDX), transmission electron microscopy (TEM), diffuse reflectance spectroscopy (DRS) and Brunauer-Emmett-Teller (BET) analysis. Results showed that photocatalytic efficiency was greatly influenced by 0.1 weight percent iron loading and $300{ }^{\circ} \mathrm{C}$ calcination temperature. The optimized reaction parameters were found to be the ambient temperature, working solution $\mathrm{pH} 6.2$ and $1 \mathrm{mg} \mathrm{g}^{-1}$ dose to completely decolorize RB5. The isotherm studies showed that RB5 adsorption by $\mathrm{Fe}-\mathrm{TiO}_{2}$ followed the Langmuir isotherm with maximum adsorption capacity of $42.7 \mathrm{mg} \mathrm{g}^{-1}$ and $\mathrm{K}_{\mathrm{ads}} 0.0079 \mathrm{~L} \mathrm{mg}^{-1}$. Under illumination, the modified photocatalytic material had higher decolorization efficiency as compared to unmodified photocatalyst. Kinetic studies of the modified material under visible light irradiation indicated the reaction followed the pseudo-first-order kinetics. The illumination reaction followed the LangmuirHinshelwood (L-H) model as the rate of dye decolorization increased with an incremental increase in dye concentration. The $\mathrm{L}-\mathrm{H}$ constant $\mathrm{K}_{\mathrm{c}}$ was $1.5542 \mathrm{mg} \mathrm{L}-1 \cdot \mathrm{h}^{-1}$ while $\mathrm{K}_{\mathrm{ads}}$ was found $0.1317 \mathrm{~L} \mathrm{mg}^{-1}$. The best photocatalyst showed prominent percent reduction of $E$. coli in $120 \mathrm{~min}$. Finally, $0.1 \mathrm{Fe}^{-} \mathrm{TiO}_{2}-$ 300 could be an efficient photocatalyst and can provide a composite solution for RB5 decolorization and bacterial strain inhibition.
\end{abstract}

Keywords: water disinfection; photo inhibition activity of $\mathrm{TiO}_{2} ; \mathrm{RB} 5$ reaction kinetics

\section{Introduction}

Wastewater generation whether industrial or domestic by rapid industrialization and/or urbanization and its discharge into natural drainage system has severely affected the fragile aquatic environment and thus becoming the principal source of toxic contaminants and pathogen dissemination. Higher volume of wastewater loaded with complex and 
versatile nature of contaminants including dyes is hot environmental issue and aggravating the environmental concerns around the globe. Strict effluent discharge laws have made the industry and wastewater researchers to explore the efficient technologies for the provision of composite treatment solutions which could meet simultaneously the dye decolorization and pathogens killing and ultimately meet the safe water quality standards. Currently different conventional methods are employed for industrial wastewater treatment including, biological oxidation and physico-chemical methods, coagulation/flocculation [1], reverse osmosis [2], membrane filtration [3], activated carbon adsorption [4,5]. All the above methods are pollutant specific and are not capable to deactivate the harmful pathogen, more precisely, biological method provide favorable conditions for these harmful human pathogens. Moreover, the non-destructive action nature and just transferring the contamination from one phase to another as well as secondary waste generation and further necessity of treatment or pretreatment process disfavor the physico-chemical processes adoption [6,7].

Advanced oxidation process (AOP) is best way to fully decolorize organic pollutants and deactivate harmful pathogens as the non-selective nature of $\mathrm{OH}$ radicals offer this approach an additional benefit. The heterogenous photocatalytic system follows the AOP at the surface of photocatalysts due to production of electrons $\left(\mathrm{e}^{-}\right)$and holes $\left(\mathrm{h}^{+}\right)$in the conduction and valence bands through excitation of photons and this charge separation contributes to the production of $\mathrm{OH}$ radicals. $\mathrm{TiO}_{2}$ based photocatalysts are considered best heterogenous photocatalysts due to the non-toxicity and availability. However, the only hinderance in large scale application is activation requirement in UV region of the spectrum. To overcome this problem, researchers have done marvelous work in reducing bandgap through doping with impurities like Fe, Ni, Cu, N, P and S [8-10].

Doping with iron(III) has been widely investigated among different metal ions because of its distinctive electronic structure and size, that closely matches the titanium (IV) [11-13]. The electronic states of iron ions in titania lead to the creation of effective electron and holes trapping sites leading to the enhanced photocatalytic activity $[14,15]$. However, the effect of metal doping on photocatalytic activity of the synthesized nanomaterial depends on various factors including synthesis method, calcination temperature and doping level [16,17]. Different synthesis procedures have been adopted for synthesis of iron doped $\mathrm{TiO}_{2}$, including hydrothermal [18], solvothermal, wet impregnation [19], co-precipitation $[20,21]$ and sol gel method [22,23]. Sol gel method is regarded as the most employed popular method to control the particle size and crystallinity [21]. Table 1 compares different Fe doped $\mathrm{TiO}_{2}$ studies reported previously.

Table 1. Comparative studies with Fe doped $\mathrm{TiO}_{2}$.

\begin{tabular}{|c|c|c|c|c|c|}
\hline Synthesis Method & Fe Contents & $\begin{array}{c}\text { Calcination } \\
\text { Temperature }\left({ }^{\circ} \mathrm{C}\right)\end{array}$ & Pollutant & $\begin{array}{c}\text { Photocatalytic Efficiency } \\
\text { and Reaction Time }\end{array}$ & Reference \\
\hline Sol-gel & $5 \mathrm{wt} \%$ & 500 & Methylene blue & $\begin{array}{l}55.45 \% \\
240 \mathrm{~min}\end{array}$ & [24] \\
\hline $\begin{array}{c}\text { Sol-gel- } \\
\text { Hydrothermal }\end{array}$ & $0.40 \mathrm{wt} \% \mathrm{Fe}-\mathrm{TiO}_{2}$ & 200 & active yellow XRG & $\begin{array}{c}88.8 \% \text { (UV), } 64.1 \% \text { (Vis) } \\
60 \mathrm{~min}\end{array}$ & [15] \\
\hline Sol-gel & $3.0 \mathrm{~mol} \%$ & 400 & E. coli & $\begin{array}{l}100 \% \text { inactivation } \\
120 \mathrm{~min}\end{array}$ & [25] \\
\hline Sol-gel & $3.0 \mathrm{~mol} \%$ & 500 & Rhodamine 6G & $\begin{array}{c}100 \% \\
40 \mathrm{~min}\end{array}$ & [26] \\
\hline Sol-gel & $1.0 \mathrm{Fe}(\mathrm{at} \%)$ & 550 & methyl orange s & $\begin{array}{c}>80 \% \\
120 \mathrm{~min}\end{array}$ & [27] \\
\hline Sol-gel & $0.15 \mathrm{~mol} \%$ & 500 & RB5 & $\begin{array}{c}100 \\
60 \mathrm{~min}\end{array}$ & [14] \\
\hline Hydrothermal & Fe:Ti, 1:3 & N.C & RB5 & $\begin{array}{c}90 \% \\
120 \mathrm{~min}\end{array}$ & [28] \\
\hline Sol-gel & $1.62 \%$ & 450 & RB5 & $\begin{array}{l}100 \% \\
60 \mathrm{~min}\end{array}$ & [29] \\
\hline Co-precipitation & & 500 & RB5 & $\begin{array}{l}91 \% \\
60 \mathrm{~min}\end{array}$ & [20] \\
\hline
\end{tabular}


Although a lot of research work has been reported for air and water purification through $\mathrm{TiO}_{2}$ photocatalysts, but a little attention has been given to water decontamination and remediation of various kinds of microbial contaminants using these semiconductors. Recently, some researcher considered Ag doped metal oxides for destroying human pathogens due to the antimicrobial activity of $\mathrm{Ag}[30,31]$ but the other doped metal or nonmetal has not yet been explored for their antimicrobial activity. Current investigation focused the synthesis and characterization of $\mathrm{Fe}-\mathrm{TiO}_{2}$ photocatalyst and its application in decolorizing the double azo reactive black 5 (RB5) dye, but focus has been given to explore the potential of $\mathrm{Fe}$ doped $\mathrm{TiO}_{2}$ for deactivation of model human pathogen E. coli. Initially $\mathrm{Fe}-\mathrm{TiO}_{2}$ was screened out for $\mathrm{Fe}$ loading and calcination temperatures and the best combination was optimized for RB5 decolorization and E. coli.

\section{Materials and Methods}

\subsection{Materials}

Titanium tetra-isopropoxide (TTIP) with a purity of $98 \%$ was supplied by Daejung, South Korea. Absolute ethanol and glacial acetic acid with a purity of $99 \%$ were purchased from Merck Darmstadt, Germany. Deionized water was produced using B114 deionizer in the laboratory. Iron nitrate and the commercial reactive black 5 (RB5), an azo dye, were acquired from Sigma Aldrich, Munich, Germany.

\subsection{Synthesis of $\mathrm{TiO}_{2}$ and $\mathrm{Fe}-\mathrm{TiO}_{2}$ Photocatalysts}

The modified sol-gel method was used to synthesize $\mathrm{TiO}_{2}$ photocatalysts [32]. Precisely, $37 \mathrm{~mL}$ TTIP was poured to $60 \mathrm{~mL}$ absolute ethanol and designated as solution A. In addition, a second solution B was generated by blending $10 \mathrm{~mL}$ deionized water and $15 \mathrm{~mL}$ acetic acid in $20 \mathrm{~mL}$ absolute ethanol. Under intense stirring, solution B was added dropwise to solution $\mathrm{A}$. The solution was stirred at room temperature $\left(25^{\circ} \mathrm{C} \pm 1\right)$ until gel was formed. The obtained gel was aged for $24 \mathrm{~h}$ under ambient conditions, dried in oven (UN 30, Memmert-Kupfer, Dominik, Germany), and ground to powder. $\mathrm{Fe}^{-\mathrm{TiO}_{2}}$ photocatalysts were synthesized by the modified synthesis method. The iron precursor was introduced to solution B prior to adding solution B to solution A, pursued by the process as reported above. Different Fe weight percent including 0.01, 0.05, 0.1, 0.5, 1 and 5

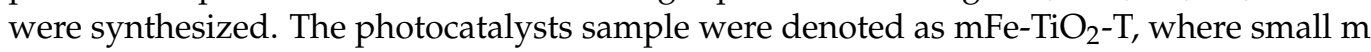
represents the weight percent, Fe represents the iron, $\mathrm{TiO}_{2}$ shows the titanium and capital $\mathrm{T}$ represents the calcination temperature for example $0.1 \mathrm{Fe}-\mathrm{TiO}_{2}-200$ shows the 0.1 weight percent iron loading onto titania and calcined at $200^{\circ} \mathrm{C}$.

\subsection{Photocatalyst Characterization}

The best performing photocatalysts were chosen for characterization of the various physicochemical properties like thermal stability, functional groups, identification of phases and crystallite size, surface morphology, bandgap estimation and surface area analysis using thermal gravimetric analyses (TGA-STA 8000, Boston, Massachusetts, United States), Fourier-transformed infrared spectroscopy (FTIR-Alpha Bruker, Karlsruhe, Germany), X-ray diffraction (XRD-Bruker, Billerica, Massachusetts, United States), scanning electron microscopy coupled with energy dispersive X-ray analysis (JEOL, JSM-6510LA, Tokyo, Japan), transmission electron microscopy (TEM), and diffuse reflectance spectroscopy (DRS-UV-2600i, Kyoto, Japan) and Brunauer-Emmett-Teller (BET) analyses, respectively. XRD was realized at $40 \mathrm{kV}, 40 \mathrm{~mA}$ in the scanning angle $(2 \theta)$ range of $10-80^{\circ}$ at scan rate of $2^{\circ} \mathrm{min}^{-1}$ using diffractometer equipped with a $\mathrm{Cu} \mathrm{K} \alpha$ radiation source. The standard diffraction data was compared, and unknown components were recognized. Scherrer formula (Equation 1) was utilized for estimation of particle sizes (D) of nanomaterial [33].

$$
D=\frac{K \lambda}{\beta \cos \theta}
$$


The Scherrer constant $(K)$ represents the particle shape and usually the $K$ value is considered to be 0.9 [34], $\lambda$ exhibits the wavelength, $\theta$ indicates the diffraction angle and $\beta$ denotes the full width at half maximum (FWHM) of the reflection peak.

\subsection{RB5 Decolorization}

RB5 decolorization was investigated at 30 ppm of dye, initial pH 6.2 and $\mathrm{Fe}^{-\mathrm{TiO}_{2}}$ dose of $1 \mathrm{~g} \mathrm{~L}^{-1}$ under a visible light source at ambient temperature. The required amount of RB5 was taken to constitute 30 ppm solution in total volume of $30 \mathrm{~mL}$. Initially the $\mathrm{Fe}^{-\mathrm{TiO}_{2}}$ was weighed and blended with distilled water followed by $10 \mathrm{~min}$ of ultrasonication. For the dark reaction, the mixture was stirred with a magnetic stirrer for $30 \mathrm{~min}$, and later the same suspension was illuminated for 60 min under visible light source of $500 \mathrm{~W}$ with 30798 lux light intensity (Halogen lamp, Hi Luminar-Germany,) at $25 \mathrm{~cm}$ distance. Figure S1, supplementary information represents the light spectrum reported in current investigation. RB5 adsorption (dark) and decolorization (light) was monitored in the samples collected at pre-determined time intervals.

\subsection{Optimization Studies}

RB5 decolorization was examined through absorbance measurements at $598 \mathrm{~nm}$ wavelength by UV-visible spectrophotometer (PG instruments T80 ${ }^{+}$, Lutterworth, UK). The standard solutions of RB5 with 1, 10, 20, 30, 50, 60 and 100 ppm concentrations were used to develop the calibration curve. The reaction mixture was centrifuged to remove suspended particles of photocatalysts each time prior to the absorbance measurement. RB5 decolorization efficiency was determined using the Equation (2).

$$
\text { RB5 Decolorization }(\%)=\left(\frac{\mathrm{C}_{0}-\mathrm{C}_{\mathrm{t}}}{\mathrm{C}_{0}}\right) 100
$$

where $\mathrm{C}_{0}$ and $\mathrm{C}_{\mathrm{t}}$ indicate, respectively, the initial and the residual RB5 concentration at time, $t$. The photocatalytic system was optimized based on RB5 decolorization investigations for reaction parameters including the contact time, $\mathrm{pH}, \mathrm{Fe}-\mathrm{TiO}_{2}$ dose and $\mathrm{RB} 5$ concentration.

\subsection{Adsorption Isotherms}

The best performing photocatalyst, $0.1 \mathrm{Fe}-\mathrm{TiO}_{2}-300$, were used to study the adsorption pathways of RB5 in the dark. The two well-known adsorption isotherms namely Freundlich and Langmuir were fitted to RB5 adsorption data analyzed under in the dark and the mechanism of RB5 adsorption was delineated. The linearly transformed Langmuir model (Equation (3)) was applied to determine the value of $Q_{m}$ and $K_{a d s}$ from the intercept $\left(1 / Q_{m}\right)$ and slop $\left(1 / Q_{m} \cdot K_{a d s}\right)$ of plot $1 / Q_{e}$ versus $1 / C_{e}$.

$$
\frac{1}{Q_{e}}=\frac{1}{Q_{m}}+\left(\frac{1}{K_{a d s} Q_{m}}\right) \frac{1}{C_{e}}
$$

The linear expression of Freundlich model can be represented by Equation (4).

$$
\ln \left(Q_{e}\right)=\ln \left(K_{F}\right)+\frac{1}{n} \ln C_{e}
$$

$Q_{e}\left(\mathrm{mg} \cdot \mathrm{g}^{-1}\right)$ indicates the quantity of RB5 adsorbed per unit weight of $\mathrm{Fe}-\mathrm{TiO}_{2}$ at the equilibrium time, $Q_{m}\left(\mathrm{mg} \cdot \mathrm{g}^{-1}\right)$ exhibits the maximum adsorption capacity of Fe$\mathrm{TiO}_{2}$ for $\mathrm{RB} 5, \mathrm{C}_{e}\left(\mathrm{mg} \cdot \mathrm{L}^{-1}\right)$ denotes the residual concentration of the dye at equilibrium. $K_{a d s}\left(\mathrm{~L} \cdot \mathrm{mg}^{-1}\right)$ indicates Langmuir adsorption constant. The Freundlich constants, i.e., $K_{F}$ and $n$, exhibit the adsorption capacity and heterogeneity factor, respectively. 


\subsection{Photocatalytic Kinetics}

In the presence of $\mathrm{Fe}^{-} \mathrm{TiO}_{2}$ photocatalyst, the Langmuir-Hinshelwood model [35] can be employed to elaborate the rate of the photocatalytic decolorization of RB5 dye over time. Langmuir-Hinshelwood model for photocatalytic system can be explained as:

$$
\frac{1}{r_{0}}=\frac{1}{k_{c}}+\frac{1}{k_{c} K_{L H}} \cdot \frac{1}{[R B 5]_{e}}
$$

The dependency of $1 / \mathrm{r} 0$ for the corresponding $1 /[R B 5]_{e}$ concentration values of RB5 can be translated by Equation (5). In comparison, the $\mathrm{k}_{\mathrm{c}}$ and $\mathrm{K}_{\mathrm{LH}}$ values demonstrate the effect of the RB5 concentration on the equilibrium constant.

\subsection{Photocatalytic Disinfection Performance Evaluation}

To check the photocatalytic disinfection ability of the $\mathrm{Fe}-\mathrm{TiO}_{2}$ photocatalyst, bactericidal activity was conducted using the best performing $\mathrm{Fe}-\mathrm{TiO}_{2}$ photocatalyst (screened from RB5 decolorization experiments). Antibacterial activities of $\mathrm{Fe}-\mathrm{TiO}_{2}$ photocatalyst were tested using different parameters (irradiation time and photocatalyst calcination temperatures) against Escherichia coli (ATCC-25922) as model pathogen. Detailed antimicrobial protocol followed is reported in our recent publication [30,36]. Data were presented with the following formula in relation to a percent reduction before and after inhibition treatment of model pathogen.

$$
\text { Reduction }(\%)=\left(\frac{A-B}{A}\right) \times 100
$$

A and B reveal the number of viable bacteria, respectively, before and after photocatalytic oxidation.

\subsection{Energy Efficiency and Cost Analysis}

Energy efficiency was estimated through electrical energy consumption (EE/O) for the best synthesized photocatalysts from each combination using the following equation [37].

$$
E_{E / O}=\frac{(p t) 1000}{\left[(V) 60 \ln \left(\frac{C_{0}}{C_{f}}\right)\right.}
$$

\section{Result and Discussion}

\subsection{Thermal Analysis}

Thermogravimetric studies were conducted for as synthesized raw $0.1 \mathrm{Fe}-\mathrm{TiO}_{2}$ photocatalyst to select the suitable calcination temperature. Figure 1 shows the weight loss profile of raw $0.1 \mathrm{Fe}-\mathrm{TiO}_{2}$ photocatalyst. Two weight loss steps are evident from the TGA profile, $5.98 \%$ weight loss occurred in step I that is from room temperature to $260{ }^{\circ} \mathrm{C}$ while $2.30 \%$ weight loss was observed in step II from 260 to $490^{\circ} \mathrm{C}$. Total weight loss in these two steps was $8.28 \%$.

In step I, from room temperature to $200^{\circ} \mathrm{C}$, solvents were evaporated while thermal decolorization of loosely bound organics occurred up till $260^{\circ} \mathrm{C}$. In step II, thermal decomposition of tightly bound organic residues and crystallization of the anatase phase occurred above $260^{\circ} \mathrm{C}$. Our results support the previous work [38]. 


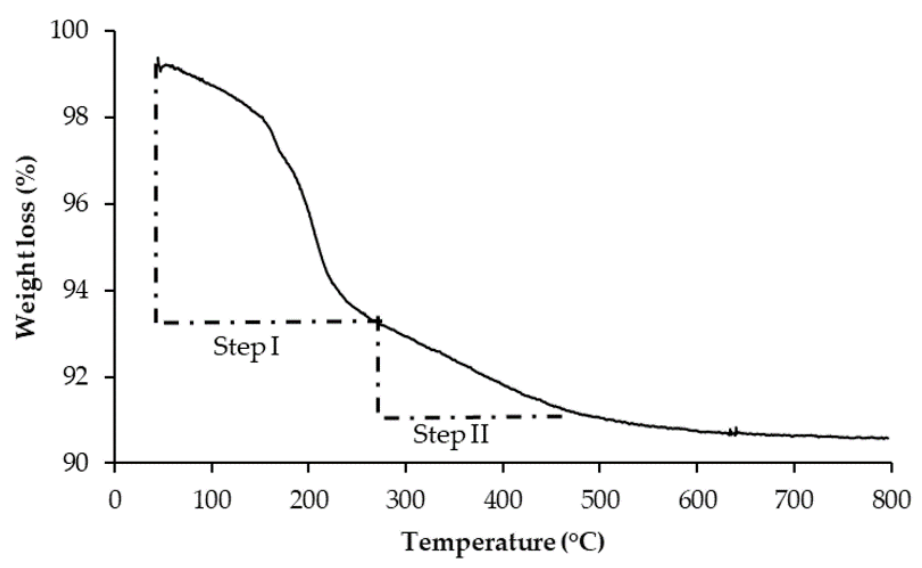

Figure 1. TG weight loss profile of $0.1 \mathrm{Fe}-\mathrm{TiO}_{2}$ photocatalyst.

\subsection{Functional Group Identification}

The FTIR spectra provides evidence about the molecular geometry and interactions of the functional groups existing in the system. FTIR spectra of $\mathrm{TiO}_{2}-300$ and $0.1 \mathrm{Fe}-\mathrm{TiO}_{2}-300$ photocatalysts can be observed in Figure 2. The band at $3450 \mathrm{~cm}^{-1}$ is ascribed to the stretching mode of $\mathrm{OH}$ group on the $\mathrm{TiO}_{2}$ in both samples [39], corresponds to the presence of water molecules. The $\mathrm{OH}$ group serves as a scavenger for the produced charge carrier, leading $\mathrm{OH}$ radical formation. In decolorization of the $\mathrm{RB} 5$ dye, this $\mathrm{OH}$ radical plays a major role as they are highly reactive species with high redox potential $(2.8 \mathrm{~V})$, and able to oxidize soluble inorganic and organic substances. FTIR spectrum also indicates that the absorbance rate is higher in the IR region $\left(1632 \mathrm{~cm}^{-1}\right)$ [36], indicating the surface hydroxylation upon doping $\mathrm{TiO}_{2}$ with $\mathrm{Fe}$. Ti-O stretching appeared between $520-735 \mathrm{~cm}^{-1}$ [40]. These bands serve an active role in improving the efficiency of photocatalysts for RB5 decolorization [39].

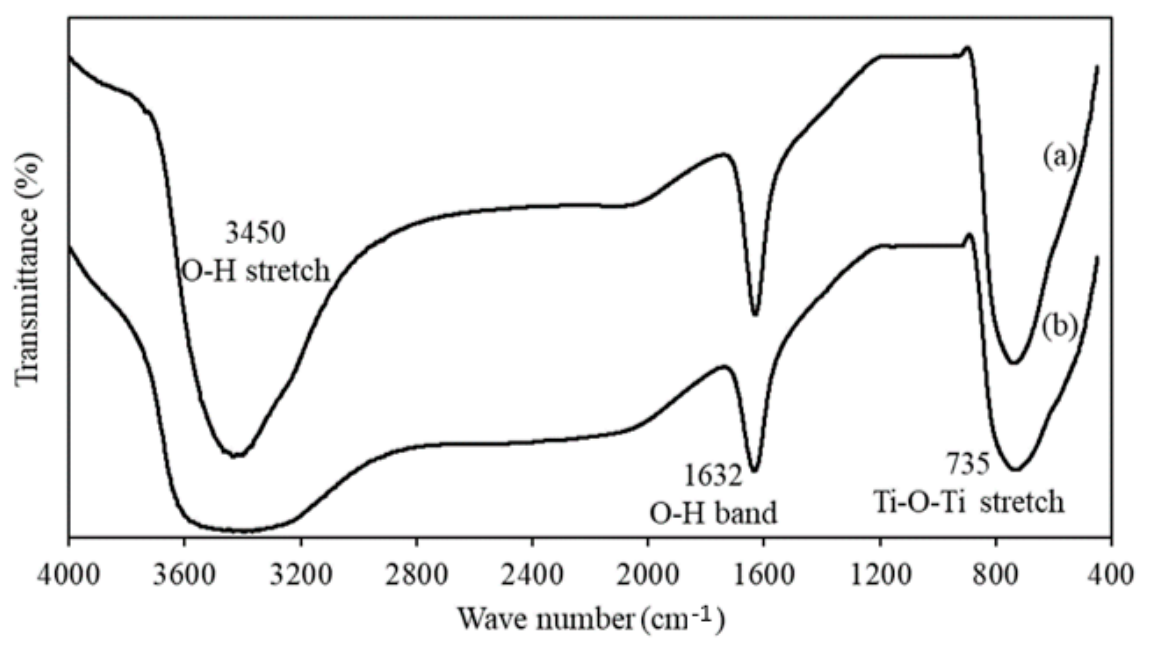

Figure 2. FTIR spectra of (a) $\mathrm{TiO}_{2}-300$; (b) $0.1 \mathrm{Fe}-\mathrm{TiO}_{2}-300$.

\subsection{X-ray Diffraction Analysis}

Figure 3 displays $\mathrm{X}$-ray diffraction analysis of $\mathrm{TiO}_{2}$ (pure anatase) and $0.1 \mathrm{Fe}-\mathrm{TiO}_{2}-300$ nanomaterials. The diffraction peaks are well allocated to the crystalline $\mathrm{TiO}_{2}$ anatase (JCPDS 84-1286). In addition, no peaks for the rutile and brookite phases were observed at $0.1 \mathrm{Fe}-\mathrm{TiO}_{2}-300$. The development of $\mathrm{TiO}_{2}$ crystals is evident in the anatase phase of $\mathrm{TiO}_{2}$ as the XRD peak intensities are weakened and expanded upon doping with iron. Similar observations were documented for $\mathrm{Fe}-\mathrm{N} / \mathrm{TiO}_{2}$ [41]. No indications were seen for the presence of Fe species in all the XRD patterns. This may be due to high 
dispersion of Fe species and the low metal content. This is well explained in our previous studies $[33,42]$. The FWHM of prominent anatase $\left(2 \theta=25.2^{\circ}\right)$ exhibits the $\left(\begin{array}{lll}1 & 0 & 1\end{array}\right)$ plane diffraction. The crystallite size was calculated using equation (1). The broad peaks confirm the occurrence of small crystallite having mean size of $5.93 \mathrm{~nm}$ and $45.11 \mathrm{~nm}$, respectively, for $0.1 \mathrm{Fe}-\mathrm{TiO}_{2}-300$ and $\mathrm{TiO}_{2}$ anatase. Crystallite size for $0.1 \mathrm{Fe}-\mathrm{TiO}_{2}-350$ was exhibited as 9.91 and reduction in crystallite size of $\mathrm{TiO}_{2}$ by Fe doping has also been reported previously $[43,44]$.

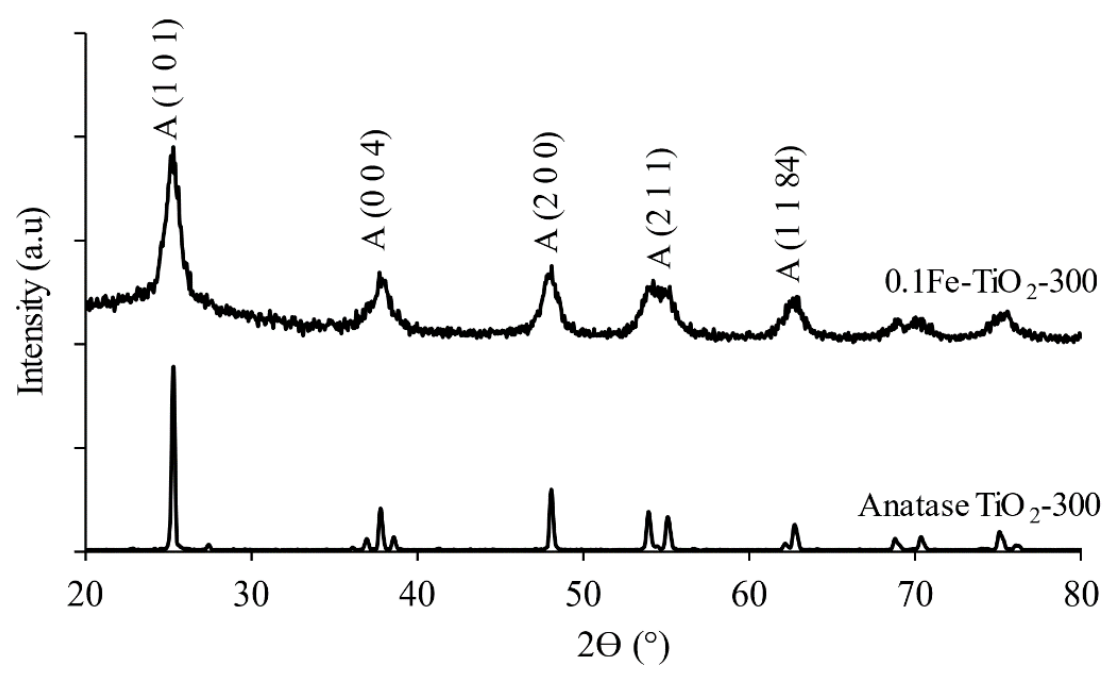

Figure 3. XRD peaks of anatase $\mathrm{TiO}_{2}-300$ and $0.1 \mathrm{Fe}-\mathrm{TiO}_{2}-300$.

\subsection{Scanning Electron Microscopy (SEM) and Transmission Electron Microscopy (TEM) Analyses}

SEM was used to study the crystallite shape, size, and metal dispersion while elemental composition was quantified using EDX analysis. Figure 4 demonstrates the spherical morphology of particles with increased agglomeration, and no localized metal particles have been observed exhibiting high iron dispersion on the surface of $\mathrm{TiO}_{2}$. The EDX spectrum shows very small intensities of $\mathrm{Fe}$ in the $0.1 \mathrm{Fe}-\mathrm{TiO}_{2}-300$ photocatalysts. Similar observations were reported previously for different Fe doped $\mathrm{TiO}_{2}$ photocatalysts $[38,45]$.

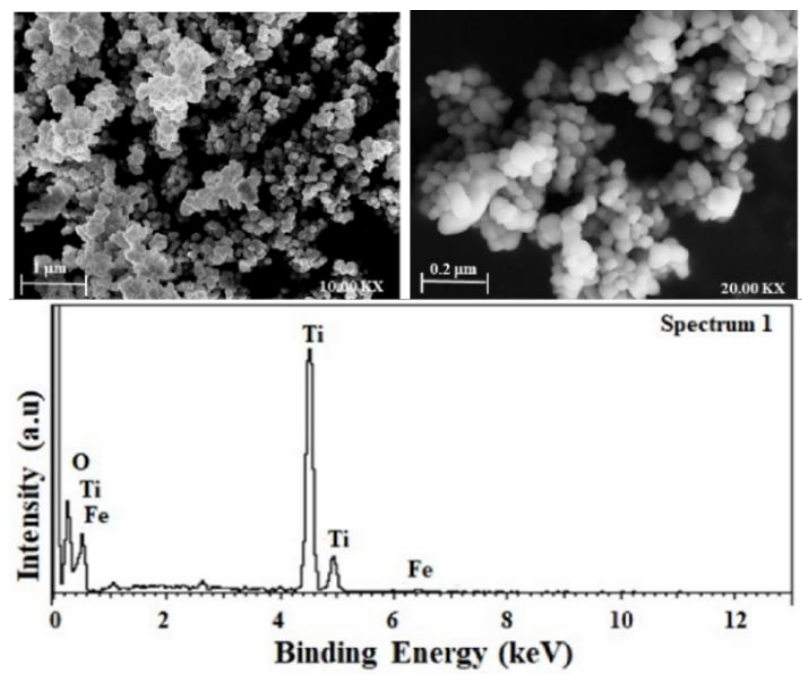

Figure 4. Scanning electron micrographs (SEM-EDX) of $0.1 \mathrm{Fe}-\mathrm{TiO}_{2}$ calcined at $300{ }^{\circ} \mathrm{C}$.

TEM micrograms have been used to observe the microstructure for further study of individual grain and grain boundaries. TEM micrographs of $0.1 \mathrm{Fe}-\mathrm{TiO}_{2}-300$ photocatalysts are displayed in Figure 5a while histogram of particle size distribution is shown in 
Figure $5 \mathrm{~b}$. It can be seen from the TEM micrographs that particles adhere to each other and are in good agreement with SEM images. The average particle size of $0.1 \mathrm{Fe}-\mathrm{TiO}_{2}{ }^{-}$ 300 was $7.82 \pm 4.22 \mathrm{~nm}$. These results are in close agreement with that obtained for crystallite size in XRD analysis. The particles stickiness can be associated to different phenomenon, as explained by previous study [46]. Moreover, in one of the previous works by Solani et. al., 2019, the average crystalline size reported was $13 \pm 2.52 \mathrm{~nm}$ [44].
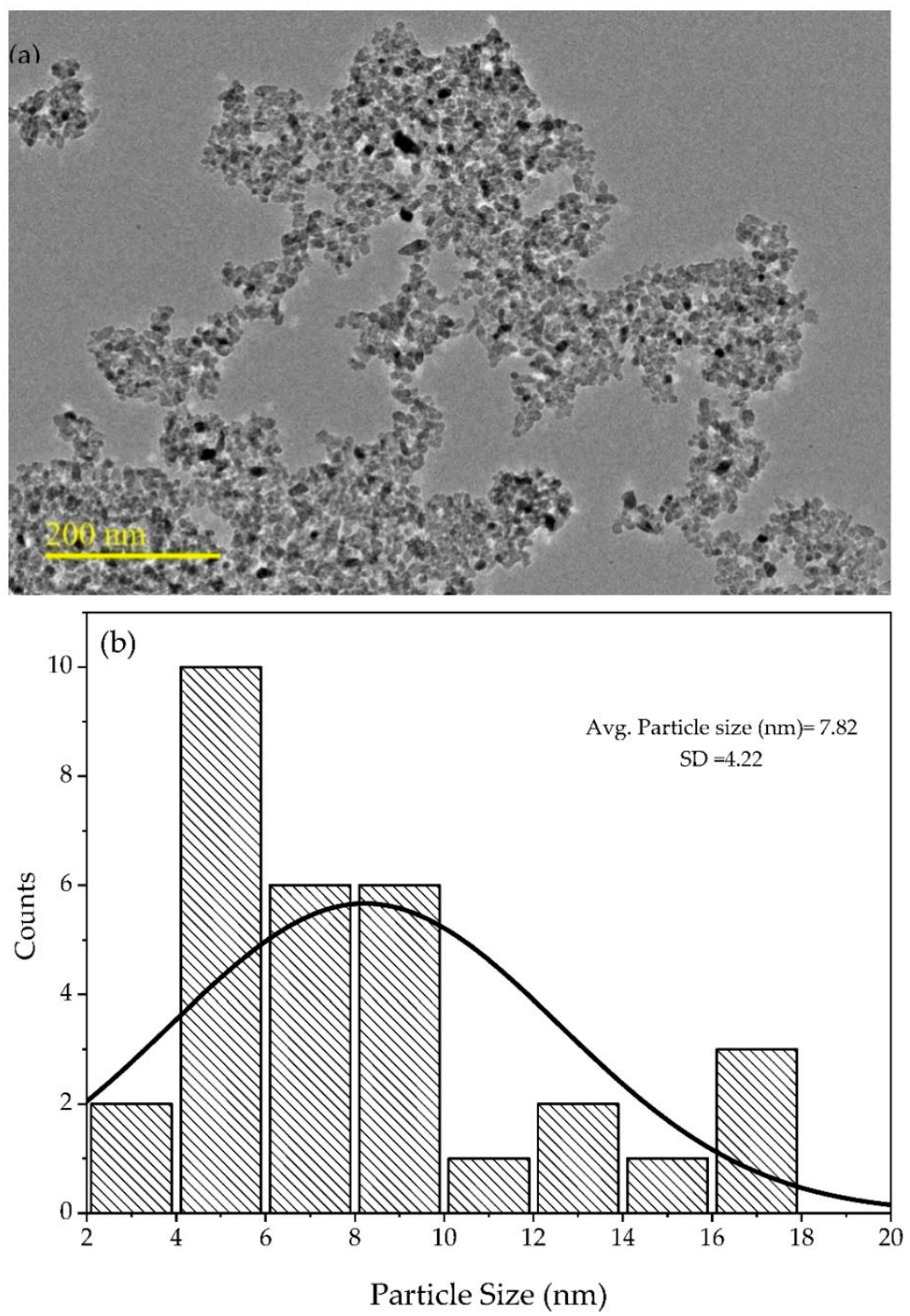

Figure 5. (a)TEM micrographs and (b) size distribution histogram of $0.1 \mathrm{Fe}-\mathrm{TiO}_{2}-300$.

\subsection{Bandgap Analysis}

The task of allowing $\mathrm{TiO}_{2}$ to operate in the visible light source is to modify its lattice structure by adding some impurities. Diffuse reflectance spectroscopy was used to observe this shift. Figure $6 \mathrm{a}$ shows the reflectance spectrum of $\mathrm{TiO}_{2}-300$, and $0.1 \mathrm{Fe}-\mathrm{TiO}_{2}-300$ photocatalysts. A visible shift of the optical absorption thresholds was observed for $0.1 \mathrm{Fe}-$ $\mathrm{TiO}_{2}-300$ compared to $\mathrm{TiO}_{2}-300$. The sharp absorption edge of around $390 \mathrm{~nm}$ was assigned to the excitation of the electron from VB to CB [47]. Tauc model is generally used to describe the light absorption process of amorphous semiconductors and estimate the band gap [48]. From the plot of $(\mathrm{F}(\mathrm{R}) \cdot \mathrm{hv})^{1 / 2}$ versus hv, the photocatalysts' bandgap energy was calculated. The photocatalyst's bandgap yielded by extrapolating it to the tangent of the 
graph in the low energy range (hv) axis when $[\mathrm{F}(\mathrm{R}) \cdot \mathrm{hv}]^{1 / 2}=0$ as shown in Figure $6 \mathrm{~b}$, while method of estimation is explained in Figure S2. The bandgap $\mathrm{TiO}_{2}-300$, and $0.1 \mathrm{Fe}-$ $\mathrm{TiO}_{2}-300$ photocatalysts was found to be 3.20 and $2.99 \mathrm{eV}$, respectively. This demonstrates a significant increase in the light absorption ability in the visible region for the iron-doped $\mathrm{TiO}_{2}$ sample.

(a)

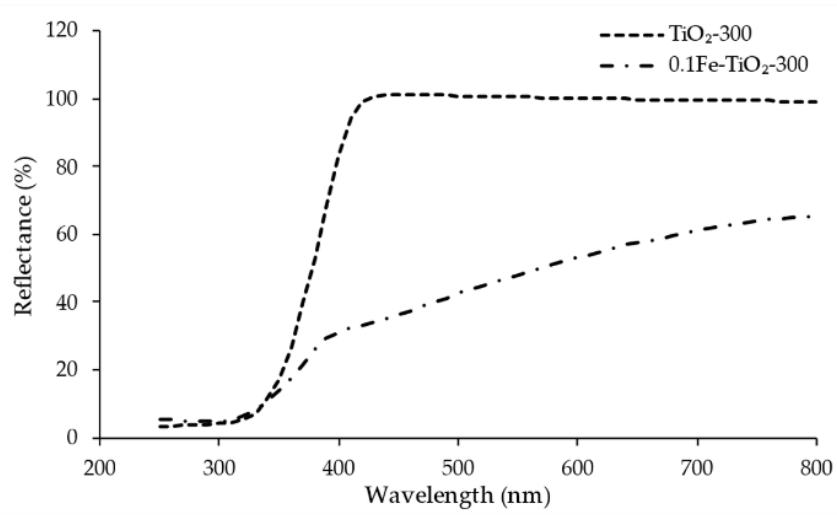

(b)

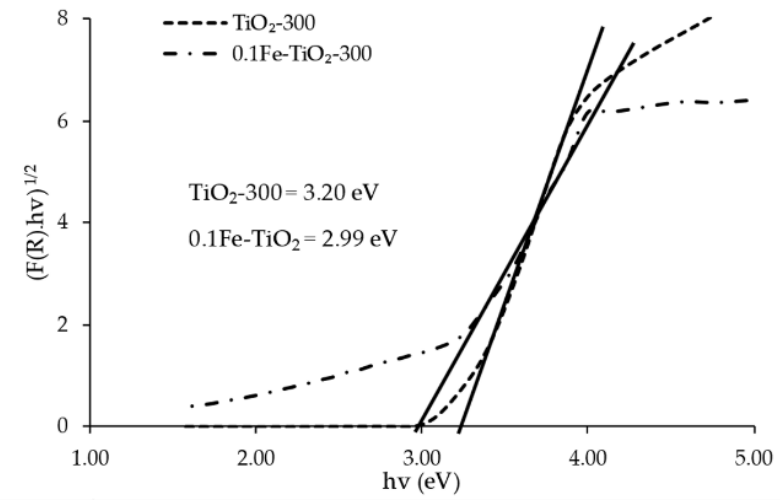

Figure 6. (a) Reflectance spectrum; (b) Tauc plot for bandgap estimation of $\mathrm{TiO}_{2}-300$ and $0.1 \mathrm{Fe}-\mathrm{TiO}_{2}-300$ photocatalysts.

\subsection{BET Analysis}

Figure 7 demonstrate the nitrogen adsorption-desorption curve for $0.1 \mathrm{Fe}-\mathrm{TiO}_{2}-300$. The adsorption isotherms of nitrogen at $77 \mathrm{~K}$ were obtained using eight values of relative pressure ranging from 0.05 to 1 . Pore size distribution curve was calculated from the desorption (DES) branch of the nitrogen isotherm by the Barrett-Joyner-Halenda (BJH) method and the corresponding nitrogen adsorption-desorption isotherms (ADS-DES) of the photocatalysts $[49,50]$. BET type II curve was observed, indicating the mesoporous nature of $0.1 \mathrm{Fe}-\mathrm{TiO}_{2}-300$ photocatalyst with mean pore diameter of $6.83 \mathrm{~nm}$. In type II isotherm the flat region in the middle represents the formation of monolayer. Such mesoporous photocatalysts are preferred generally for photocatalytic decolorization because higher porosity of photocatalysts favors adsorption of dye molecules. BET results showed the surface area for $0.1 \mathrm{Fe}-\mathrm{TiO}_{2}-300$ as $70 \mathrm{~m}^{2} \mathrm{~g}^{-1}$ with pore volume of $0.115 \mathrm{~cm}^{3} \mathrm{~g}^{-1}$. Results from adsorption studies best fit with Langmuir adsorption isotherm showing the formation of monolayer chemisorption mechanism, which agree with $\mathrm{N}_{2}$ adsorption desorption analysis.

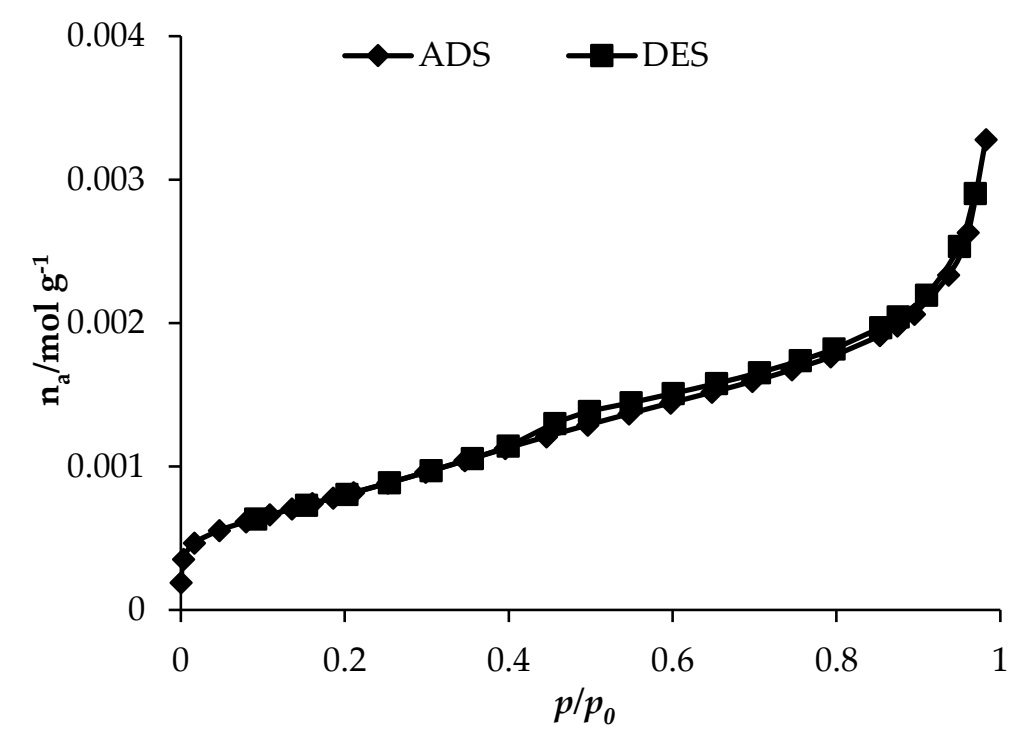

Figure 7. $\mathrm{N}_{2}$ adsorption/desorption isotherms of the $0.1 \mathrm{Fe}-\mathrm{TiO}_{2}-300$ photocatalyst. 


\subsection{Photodecolorization Studies}

\subsubsection{Effect of Photocatalyst Dose}

Mass of the photocatalyst is directly proportional to the rate of reaction, however after a certain amount of dose the reaction rate levels off. This phenomenon is well explained in previous studies through masking of the photocatalyst surface by high dose $[19,51,52]$. Therefore, it is essential to optimize the photocatalytic system with optimum dose of the photocatalysts. Experiments were performed with different $0.1 \mathrm{Fe}-\mathrm{TiO}_{2}-300$ dose i.e., 0.25 , $0.5,1,2,4$ and $8 \mathrm{mg} \mathrm{mL}^{-1}$. Figure 8 a shows that there is an increase in \% RB5 decolorization from $57 \%$ to $91 \%$ with an increase in $0.1 \mathrm{Fe}^{-} \mathrm{TiO}_{2}-300$ dose from $0.25 \mathrm{mg} \mathrm{mL}^{-1}$ to $1 \mathrm{mg} \mathrm{mL}^{-1}$ but after $1 \mathrm{mg} \mathrm{mL}^{-1}$ decrease in \% RB5 decolorization was observed and at $8 \mathrm{mg} \mathrm{mL}^{-1}$ only 48\% RB5 decolorization was exhibited. It was also observed during the experimental proceedings that at higher dose of $0.1 \mathrm{Fe}-\mathrm{TiO}_{2}-300$ the solution become turbid and light penetration into the solution was hindered, so lower $\mathrm{e}^{-} / \mathrm{h}^{+}$generation can be assumed, which resulted in lower \% RB5 decolorization. Moreover, previous studies reported the aggregation of nanoparticles at higher dose thus reduces the photocatalytic activity $[53,54]$. Therefore, the optimum dose of $0.1 \mathrm{Fe}-\mathrm{TiO}_{2}-300$ was chosen as $1 \mathrm{mg} \mathrm{mL}^{-1}$.

(a)
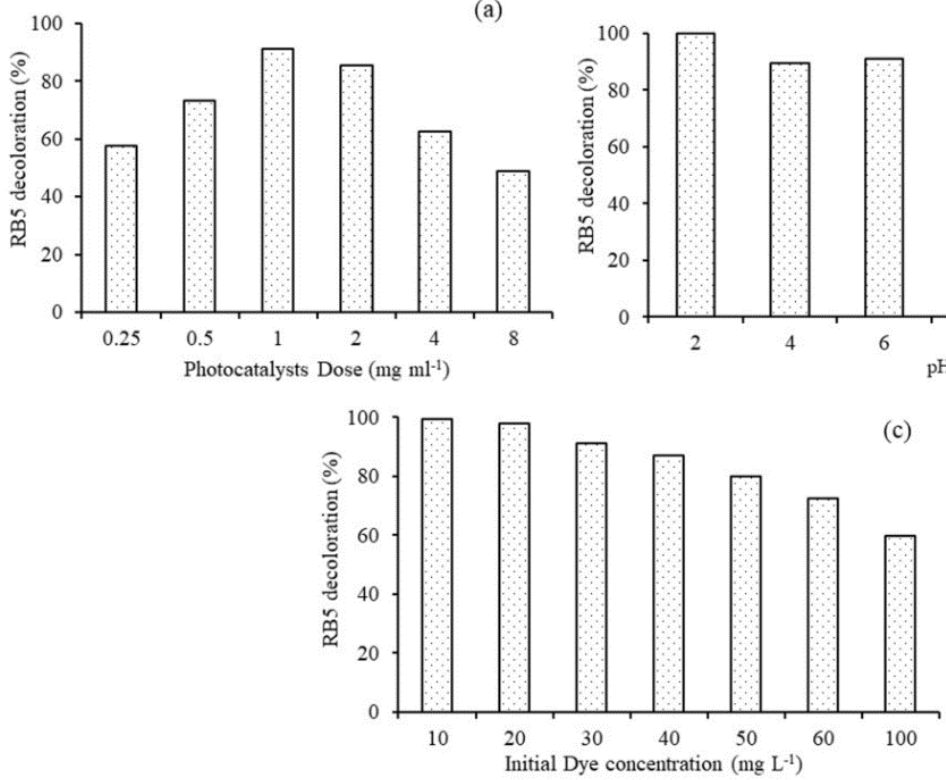

(b)

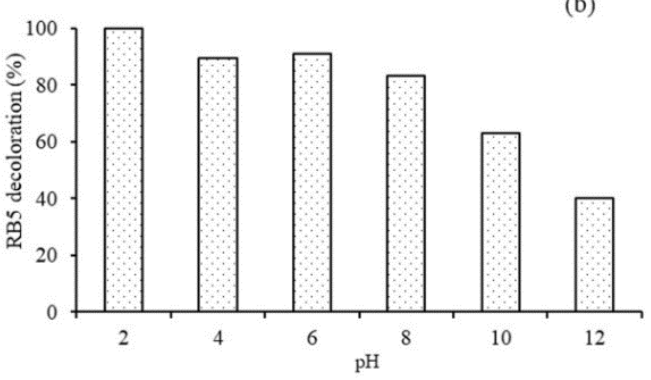

c)

Figure 8. Effect of (a) photocatalyst dose; (b) pH; (c) initial dye concentration on the percent decolorization of RB5 azo dye using $0.1 \mathrm{Fe}-\mathrm{TiO}_{2}-300{ }^{\circ} \mathrm{C}$.

\subsubsection{Effect of Reaction $\mathrm{pH}$}

The photocatalyst's surface charge, the acid base property of the metal oxide and the generation and scavenging of hydroxyl radicals are affected due to the amphoteric behavior of the semiconductor, eventually affecting the semiconductor's decolorization efficiency. Hence it is important to optimize the photocatalytic performance of $0.1 \mathrm{Fe}-\mathrm{TiO}_{2}-300$ under different $\mathrm{pH}$ conditions. Figure $8 \mathrm{~b}$ depicts the effect of variable $\mathrm{pH}$ and optimum dose of $1 \mathrm{mg} \mathrm{mL}^{-1}$ on decolorization of $0.1 \mathrm{Fe}-\mathrm{TiO}_{2}-300$ photocatalyst for RB5 dye. Best results were obtained for lower $\mathrm{pH}$ as compared to higher $\mathrm{pH} .100 \%$ decolorization was observed at $\mathrm{pH} 2$ while $40 \%$ decolorization of $\mathrm{RB} 5$ dye was observed at $\mathrm{pH} 12$. The effect of $\mathrm{pH}$ can be explained based on point of zero charge (PZC) on the surface of using $0.1 \mathrm{Fe}-\mathrm{TiO}_{2}-300$ under different $\mathrm{pH}$ conditions. The $\mathrm{PZC}$ for $\mathrm{Fe}-\mathrm{TiO}_{2}$ is between 5.6 and 6.4 [55], the Fe doped photocatalyst shall be positively charged in acidic medium while it shall be negatively charged in alkaline medium. The higher decolorization of anionic RB5 dye under acidic and lower under alkaline conditions are best explained by the above phenomenon. Due to 
similar charges on the surface of the photocatalysts and the pollutant, the electrostatic repulsion between similar charges reduces the efficiency of the system as explained in previous studies $[51,56,57]$. A similar study on rhodamine $\mathrm{B}$ photocatalysis by $\mathrm{Fe}-\mathrm{TiO}_{2}$ reported that the performance of the photocatalyst was increased when initial $\mathrm{pH}$ was augmented from 2.0 to 6.0 , because the charge of the catalyst surface was opposite to that of rhodamine $B$ and, thus, the attraction tendency was observed high $[56,58]$.

\subsubsection{Effect of Initial Dye Concentration}

It is essential to investigate the effect of pollutant concentration on the photocatalyst's decolorization efficiency from an application point of view. It is widely accepted that with an increase in dye concentration to a certain level, photocatalytic decolorization increases and further increase lower the decolorization efficiency of photocatalytic. Figure $8 \mathrm{c}$ illustrates the effect of different initial RB5 concentration at the working $\mathrm{pH}$ and $1 \mathrm{mg} \mathrm{mL}^{-1}$ of photocatalyst dose on percent RB5 decolorization. Initially at lower concentration, 10 and 20 and $30 \mathrm{mg} \mathrm{L}^{-1}$, the decolorization was observed to be 100 and $91 \%$ but further increase in RB5 concentration, 40,50, 60 and $100 \mathrm{mg} \mathrm{L}^{-1}$, the percent decolorization decreased from $87 \%, 80 \%, 72 \%$ and $60 \%$, respectively. The reduction in photocatalytic efficiency of $0.1 \mathrm{Fe}-$ $\mathrm{TiO}_{2}-300$ with increase in $\mathrm{RB} 5$ concentration can be attributed to different reasons as stated in previous studies like non-availability of active adsorption sites due to high pollutant load, interference in light penetration to the surface of $0.1 \mathrm{Fe}-\mathrm{TiO}_{2}-300$ photocatalysts for activation and lower radical production to proceed the photocatalytic process $[51,56,59,60]$. Shima et al. reported the possible reason that when the initial concentration is increased, more dye molecules are adsorbed on the surface of the $\mathrm{Fe}$ doped $\mathrm{TiO}_{2}$, thus all the surface sites for the adsorption of hydroxyl ions are blocked and, hence, lower tendency of the generation of hydroxyl radicals [57].

\subsection{4. $\mathrm{Fe}-\mathrm{TiO}_{2}$ Adsorption Studies}

Photocatalysis is an advanced oxidation process and a surface phenomenon, which leads to the decomposition of organic pollutants to $\mathrm{CO}_{2}$ and $\mathrm{H}_{2} \mathrm{O}$. Adsorption of organic compound on to the surface of photocatalysts is a crucial step in measuring the effectiveness of photocatalysts in $\mathrm{RB} 5$ decolorization. $0.1 \mathrm{Fe}-\mathrm{TiO}_{2}-300$ was selected, based on screening studies of iron loading and calcination temperature, to verify the adsorption mechanism. Figure 9a shows the effect of initial RB5 concentration (10 to $\left.100 \mathrm{mg} \mathrm{L}^{-1}\right)$ onto adsorption capacity at equilibrium $(\mathrm{Qe})$ as a function of time. Qe was calculated from the experimental data of initial concentration (Ci) minus concentration at equilibrium (Ce) multiplied by volume divided by mass of the photocatalysts. Equilibrium time was determined when most of the adsorption sites are occupied and no further adsorption-desorption took place at the surface of $0.1 \mathrm{Fe}-\mathrm{TiO}_{2}-300$. Similar results were reported in previous studies for the effect of initial dye concentration on the adsorption behavior of the $\mathrm{TiO}_{2}$ photocatalysts, where the higher percent decolorization was observed at lower concentration and with the passage of time it gets slow and becomes constant at equilibrium time [61,62]. Figure $9 \mathrm{~b}$ illustrates the amount of RB5 adsorbed at equilibrium on $0.1 \mathrm{Fe}-\mathrm{TiO}_{2}-300$ as a function of concentration at equilibrium.

The distribution of dye molecules between liquid and solid phase at equilibrium can be modelled through fitting the data to different isotherm models. Our data best fitted into the linear form of the Langmuir model (plot 1/Qe vs 1/Ce), graphically described in Figure 10a. Qm and $\mathrm{K}_{\mathrm{ads}}$ for $0.1 \mathrm{Fe}-\mathrm{TiO}_{2}-300$ are calculated as $42 \mathrm{mg} \mathrm{g}^{-1}$ and $0.0079 \mathrm{~L} \mathrm{mg}^{-1}$ respectively. To get more overview of the surface of the synthesized material, the adsorption data was fitted into Freundlich adsorption isotherm model. Plot of lnQe vs $\operatorname{lnCe}$ was constructed and shown in Figure $10 \mathrm{~b}$. The $\mathrm{K}_{\mathrm{F}}$ and $1 / \mathrm{n}$ were obtained as $1.78 \mathrm{~L} \mathrm{~g}^{-1}$ and $29.51 \mathrm{mg} \mathrm{g}^{-1}$ respectively. Summary of the isotherm constants are presented in Table 2. 
(a)

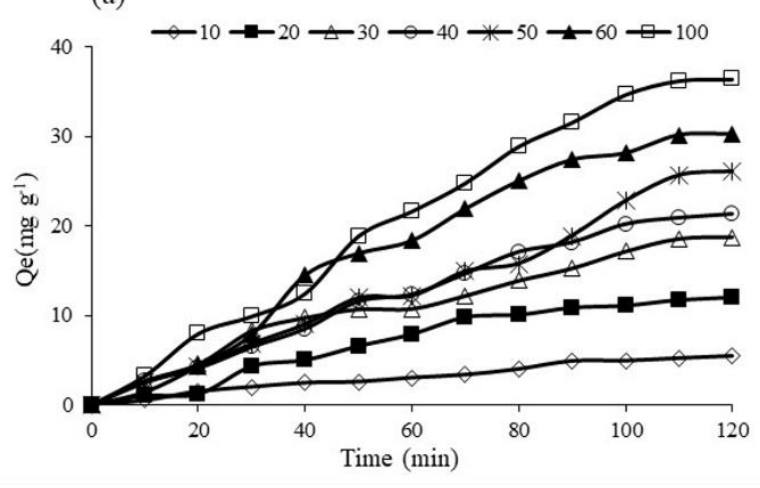

(b)

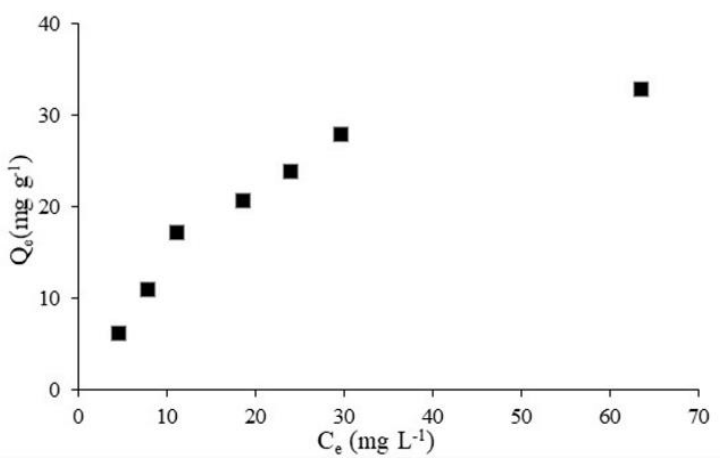

Figure 9. RB5 adsorption on $0.1 \mathrm{Fe}-\mathrm{TiO}_{2}-300$ as (a) a function of time; (b) a function of dye concentration at equilibrium $\left(\mathrm{C}_{\mathrm{e}}\right)$.
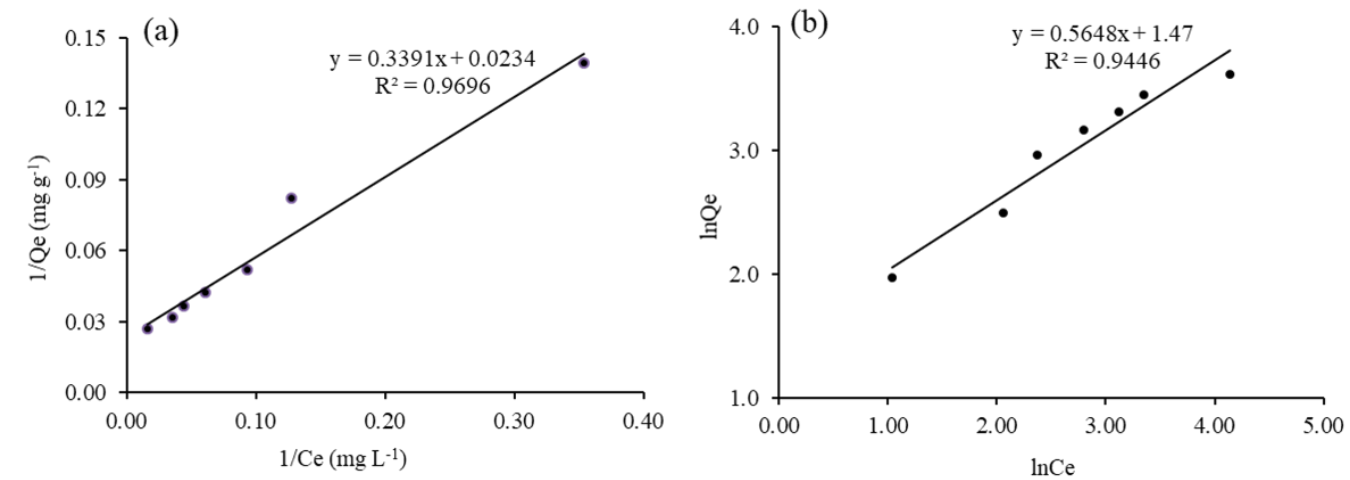

Figure 10. Transformation of (a) Langmuir; (b) Freundlich adsorption isotherm of RB5 decolorization using $0.1 \mathrm{Fe}-\mathrm{TiO}_{2}-300$.

Table 2. Summary of isotherms constants.

\begin{tabular}{cccc}
\hline Isotherm Model & Plot & Parameters & $\mathbf{R}^{\mathbf{2}}$ \\
\hline Langmuir & 1/Qe vs 1/Ce & $\mathrm{Q}_{\mathrm{m}}=42 \mathrm{mg} \mathrm{g}^{-1}$ & 0.9696 \\
& lnQe vs lnCe & $\mathrm{K}_{\mathrm{ads}}=0.0079 \mathrm{~L} \mathrm{mg}^{-1}$ & $n=1.78$ \\
Freundlich & $\mathrm{K}_{\mathrm{F}}=29.51 \mathrm{mg} \mathrm{g}^{-1}$ & 0.9446 \\
& & \\
\hline
\end{tabular}

\subsection{Heterogenous Photocatalytic Kinetic Studies for Iron Doped $\mathrm{TiO}_{2}$ Photocatalysts}

Kinetic studies were performed for the photocatalytic decolorization of RB5 azo dye using $\mathrm{Fe}_{-} \mathrm{TiO}_{2}$ photocatalysts. The optimized experimental conditions such as working $\mathrm{pH}$ (6.2), room temperature $\left(23 \pm 1^{\circ} \mathrm{C}\right)$, photocatalysts dose of $1 \mathrm{mg} \mathrm{mL}^{-1}$ were used for the kinetic study. For quantitative evaluation of different kinetic models, the data was plotted in pseudo-first-order (PFO) and pseudo-second-order (PSO) kinetic models. The plot of these kinetic models are given in Figure 11a,b respectively. To fit the data into PFO kinetics, the natural logarithm of the ratio $\ln \left([R B 5]_{e} /[R B 5]\right)$ versus the illumination time (min) was fitted. The least square regression was used to calculate the $K_{a p p}$ and $R^{2}$ for each concentration, the slope of linear regression shows the apparent PFO rate constant $k_{a p p}$. The kinetic data best fit the PFO kinetic model with $\mathrm{R}^{2}$ values ranging from $0.980-0.996$ for different concentration, while for PSO fitting the $\mathrm{R}^{2}$ value ranges from $0.650-0.981$. Therefore, the visible light driven decolorization of RB5 by $0.1 \mathrm{Fe}-\mathrm{TiO}_{2}-300$ corresponds to the PFO reaction kinetics. Generally, this model is appropriate for the whole range of RB5 from few ppm $\left(10 \mathrm{mg} \mathrm{L}^{-1}\right)$ to higher concentration $\left(100 \mathrm{mg} \mathrm{L}^{-1}\right)$, in agreement with several other previous studies on the decolorization of aqueous pollutants through $\mathrm{TiO}_{2}$ 
based photocatalysts [59,60,63-65]. The PSO kinetics (Figure 13b) does not represent the fitting of decolorization data.
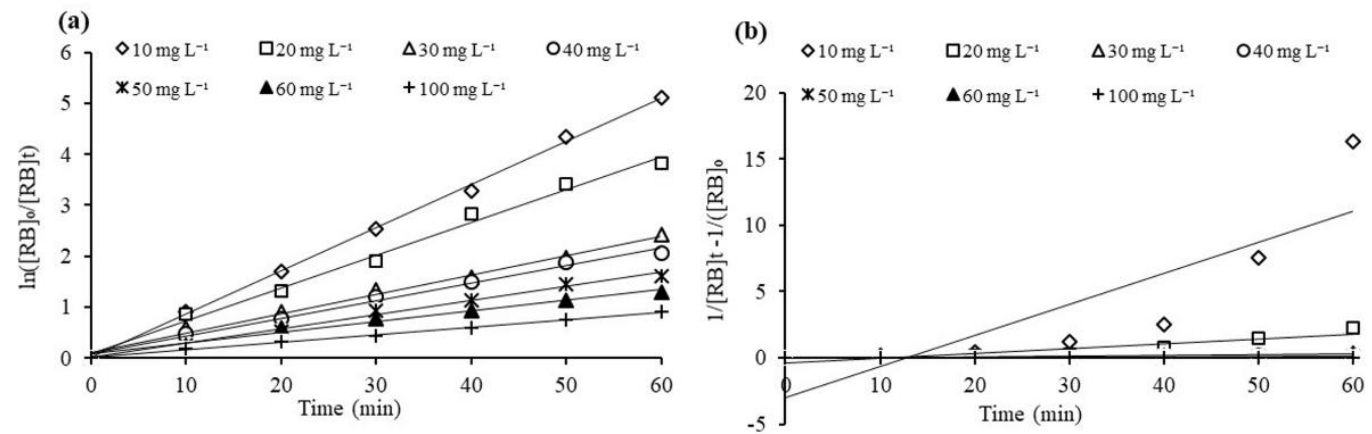

Figure 11. (a) PFO; (b) PSO kinetics of RB5 azo dye photodecolorization using $0.1 \mathrm{Fe}-\mathrm{TiO}_{2}-300$.

Langmuir-Hinshelwood isotherm model (L-H) is most used to express the heterogenous photocatalytic process $[66,67]$. The L-H kinetic expression is shown in Figure 11. The $\mathrm{L}-\mathrm{H}$ isotherm is expressed by plotting $\ln \left([\mathrm{RB}]_{0} /[\mathrm{RB}] \mathrm{t}\right)$ verses irradiation time. The PFO constant, $\mathrm{k}_{\mathrm{app}}\left(\mathrm{min}^{-1}\right)$, was calculated from the slope of the plots. To calculate the values of PFO rate constant, $\mathrm{K}_{\mathrm{C}}\left(\mathrm{mg} \mathrm{L}^{-1} \mathrm{~h}^{-1}\right)$, and L-H constant, $\mathrm{K}_{\mathrm{LH}}\left(\mathrm{L} \mathrm{mg}^{-1}\right)$, for LangmuirHinshelwood isotherm, the plot of $1 / K_{\text {app }}$ against [RB5] is constructed, shown in inset Figure 12 , depicted a straight line. The $\mathrm{K}_{\mathrm{C}}$ value, $1.554 \mathrm{mg} \cdot \mathrm{L}^{-1} \cdot \mathrm{h}^{-1}$, obtained from the slope $\left(1 / \mathrm{K}_{\mathrm{C}}\right)$ of the straight line $\left(\mathrm{R}^{2}=0.9985\right)$ and $\mathrm{K}_{\mathrm{LH}} 0.1317 \mathrm{~L} \cdot \mathrm{mg}^{-1}$, obtained from intercept $\left(1 / \mathrm{K}_{\mathrm{C}} \mathrm{K}_{\mathrm{LH}}\right)$, elaborate the effect of initial concentration of RB5 on the equilibrium constant for the adsorption-desorption processes.

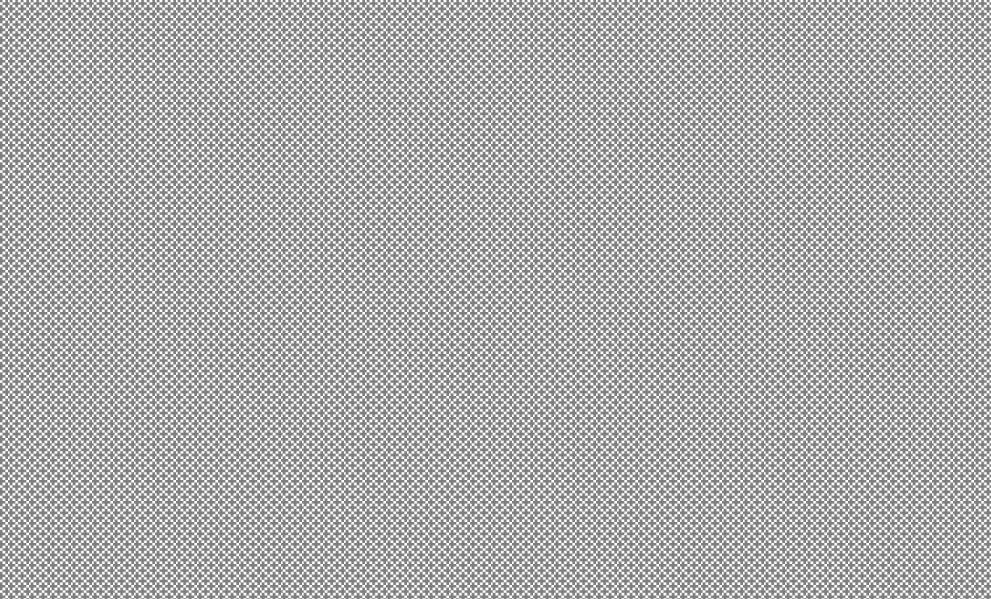

Figure 12. Effect of RB5 concentration on the initial rate of decolorization: Inset-Plot of reciprocal of apparent rate $\left(\mathrm{K}_{\mathrm{app}}\right)$.

Figure 12 confirms that the decolorization rate of $0.1 \mathrm{Fe}-\mathrm{TiO}_{2}$ augments with rising concentration of RB5, which corresponds to Langmuir-Hinshelwood adsorption model [68-70]. This plot showed that adsorption was the start of the photocatalytic process and clearly confirmed the Langmuir-Hinshelwood relationship.

According to the mechanism of the Langmuir-Hinshelwood kinetic model, the adsorption of the dye is a significant step in deciding photocatalytic degradation rates. The amount of RB5 molecules adsorbed on the surface of the photocatalyst are more vulnerable to decolorization during the photocatalytic phase. As reported previously, the heterogenous photocatalytic process is surface phenomenon and the radicals generated by excitation of photocatalysts could readily react with adsorbed dye molecules on the surface, moreover, 
this can reduce the recombination of electrons and holes and increase the photocatalytic efficiency [35,71].

\subsection{TOC Analysis}

TOC analysis was conducted for the optimized photocatalyst under optimized conditions including working $\mathrm{pH}, 1 \mathrm{mg} \mathrm{mL}^{-1}$ dose and $30 \mathrm{mg} \mathrm{L}^{-1}$ dye concentration at room temperature $(23 \pm 1)$. As can be seen in Figure 13. $60 \%$ TOC and $91 \%$ color removal was achieved in first $60 \mathrm{~min}$ for $0.1 \mathrm{Fe}-\mathrm{TiO}_{2}-300$ under visible light irradiation. Prolong exposure of $120 \mathrm{~min}$ under visible light can eliminate the color as well as TOC, so, under the optimized conditions $0.1 \mathrm{Fe}-\mathrm{TiO}_{2}-300$ photocatalysts has the ability to eliminate the $\mathrm{RB} 5$ dye. A similar kind of results are reported previously, 52\% TOC removal was achieved for $5 \% \mathrm{Fe}-\mathrm{TiO}_{2}$ photocatalysts in 120 min of irradiation [58].

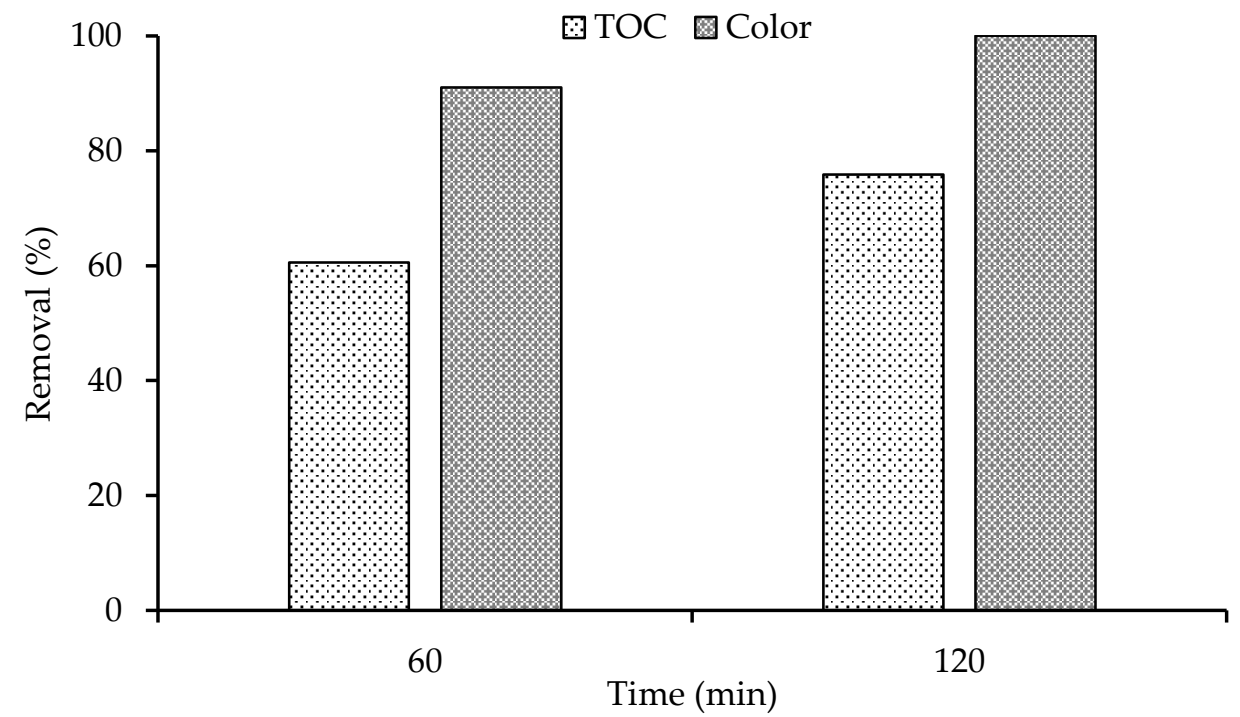

Figure 13. Comparison between decolorization and TOC removal of $\mathrm{RB} 5$ using $0.1 \mathrm{Fe}-\mathrm{TiO}_{2}-300$.

\subsection{Photocatalytic Disinfection Performance Evaluation}

Photocatalytic inhibition was conducted for $0.1 \mathrm{Fe}-\mathrm{TiO}_{2}$ photocatalysts to check the antibacterial activity against selected bacterial strain E. coli (ATCC-25922). Experiments were conducted for control (C), bare $\mathrm{TiO}_{2}-300(\mathrm{~T}), 0.1 \mathrm{Fe}-\mathrm{TiO}_{2}-200(200), 0.1 \mathrm{Fe}-\mathrm{TiO}_{2}-300$ (300), and $0.1 \mathrm{Fe}-\mathrm{TiO}_{2}-400$ (400). Control experiments are without addition of photocatalysts, and the effect of only light was observed on the deactivation of the selected bacterial strain. Initial screening results in Figure 14a shows the evidence of biocidal performance of $0.1 \mathrm{Fe}-\mathrm{TiO}_{2}$ calcined at different calcination temperatures against tested bacterial pathogen. 120 min was estimated best for $0.1 \mathrm{Fe}-\mathrm{TiO}_{2}-300$ during kill time analysis with maximum growth inhibition through Kill-time analysis. A noticeable viability of the test pathogens with the passage of time can be seen in Figure 14b.

\subsection{Energy Efficiency Analysis}

The energy consumption and price estimation for the removal of RB5 dye in $1000 \mathrm{~L}$ of wastewater was conducted through the equation 7 . The energy consumption for Bare $\mathrm{TiO}_{2}$ was found higher as compare to $0.1 \mathrm{Fe}-\mathrm{TiO}_{2}-300$. The energy consumption for iron doped $\mathrm{TiO}_{2}$ was $207 \mathrm{KWh} \mathrm{m}{ }^{-3}$ while the cost was 5309 PKR (33 USD) for $1000 \mathrm{~L}$ of textile wastewater. 
(a)

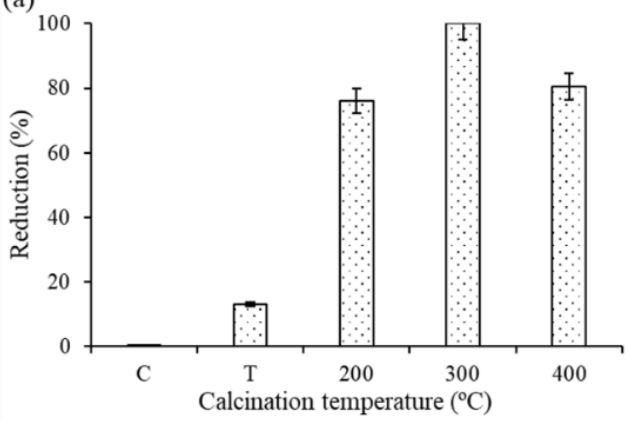

(b)

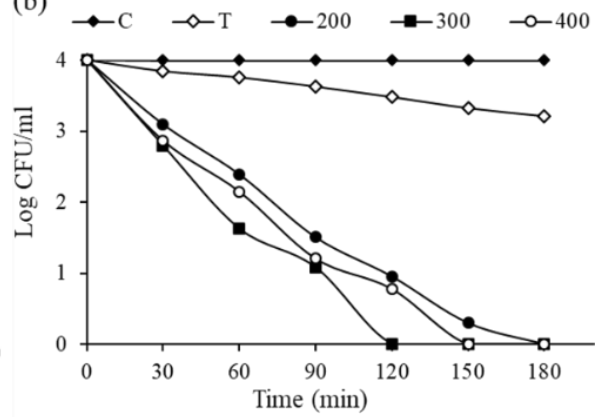

Figure 14. (a) Antibacterial performance of $\mathrm{TiO}_{2}(\mathrm{~T})$ and $0.1 \mathrm{Fe}-\mathrm{TiO}_{2}$ photocatalysts calcined at different calcination temperatures; (b) kill time analysis $\log \mathrm{CFU} \mathrm{mL}{ }^{-1}$ of $\mathrm{E}$. coli. C $=$ control, $\mathrm{T}=\mathrm{TiO}_{2}-300,200=0.1 \mathrm{Fe}-\mathrm{TiO}_{2}-200,300=0.1 \mathrm{Fe}-\mathrm{TiO}_{2}-300$ and $400=0.1 \mathrm{Fe}-\mathrm{TiO}_{2}-400$.

\section{Conclusions}

An efficient photocatalytic system for decolorization of double azo RB5 dye and water disinfection of E. coli was successfully developed. Screening studies were conducted with a series of $\mathrm{Fe}-\mathrm{TiO}_{2}$ photocatalysts synthesis via sol-gel technique and characterized using TGA, FTIR, XRD, SEM coupled with EDX, TEM, DRS and BET analyses. Iron loading and calcination temperature highly affected the photocatalytic performance of the synthesized photocatalysts. Complete decolorization of RB5 azo dye was achieved by the best selected photocatalyst $0.1 \mathrm{Fe}-\mathrm{TiO}_{2}-300$ at ambient temperature, solution working $\mathrm{pH} 6.2$ and $1 \mathrm{mg} \mathrm{g}^{-1}$ dose in $60 \mathrm{~min}$ of visible light irradiation. The isotherm studies for the adsorption showed that the modified material followed the Langmuir with $\mathrm{Q}_{\mathrm{m}}, 42.7 \mathrm{mg} \mathrm{g}^{-1}$ and $\mathrm{K}_{\mathrm{ads}} 0.0079 \mathrm{~L} \mathrm{mg}^{-1}$. Under illumination the modified photocatalytic material had higher decolorization efficiency as compared to unmodified photocatalyst. Kinetic studies of the modified material under visible light irradiation showed that the reaction follows the PFO kinetics. The illumination reaction followed the Langmuir-Hinshelwood model as the rate of dye decolorization increased with increment in initial dye concentration. The L-H constant $\mathrm{k}_{\mathrm{c}}$ was $1.5542 \mathrm{mg} \mathrm{L}^{-1} \cdot \mathrm{h}^{-1}$ while $\mathrm{K}_{\mathrm{ads}}$ was found $0.1317 \mathrm{~L} \mathrm{mg}^{-1}$. Furthermore, maximum growth inhibition and photocatalytic disinfection activity of $0.1 \mathrm{Fe}-\mathrm{TiO}_{2}-300$ photocatalyst showed a drastic decrease in viability of the test pathogens. Moreover, $0.1 \mathrm{Fe}-\mathrm{TiO}_{2}-300$ photocatalysts was more energy efficient as compared to bare $\mathrm{TiO}_{2}$. It is recommended to use solar light for higher energy efficiency.

Supplementary Materials: The following are available online at https://www.mdpi.com/2079-499 1/11/2/436/s1, Figure S1. Light spectrum of the visible light and Figure S2. Bandgap estimation from DRS spectra.

Author Contributions: Conceptualization, M.B., M.A. (Muhammad Arshad 5,*); methodology, M.S.K., J.A.S.; software, N.R.; A.J.K.; M.A. (Muhammad Arshad ${ }^{3}$ ), A.U.-H.; validation, M.S.K., J.A.S., N.R., A.J.K., M.A. (Muhammad Arshad ${ }^{5, *}$ ), and M.B.; formal analysis, M.S.K., and J.A.S.; investigation, M.S.K., and J.A.S.; resources, T.A.B., W.K., H.H.G., E.R.L., A.A.A.A.-N., A.U.-H., and M.A. (Muhammad Arshad ${ }^{3}$ ); M.A. (Muhammad Arshad ${ }^{5, *}$ ), and M.B., data curation, M.S.K., and J.A.S.; writing-original draft preparation, M.S.K., and J.A.S.; writing-review and editing, N.R., A.J.K., W.K., H.H.G., E.R.L., A.A.A.A.-N., M.A. (Muhammad Arshad ${ }^{5, *}$ ), and M.B.; visualization, M.S.K., J.A.S., A.U.-H., M.A. (Muhammad Arshad ${ }^{3}$ ), M.A. (Muhammad Arshad ${ }^{5, *}$ ) and M.B.; supervision, M.B., and M.A. (Muhammad Arshad ${ }^{5, *}$ ); project administration, W.K., H.H.G., E.R.L., A.A.A.A.-N., M.A. (Muhammad Arshad ${ }^{5, *}$ ) and M.B.; funding acquisition, W.K., H.H.G., E.R.L., A.A.A.A.-N., M.A. (Muhammad Arshad ${ }^{5, *}$ ) and M.B. All authors have read and agreed to the published version of the manuscript.

Funding: This research has been funded by Scientific Research Deanship at University of Ha'il-Saudi Arabia through project number RG-191313.

Conflicts of Interest: The authors declare no conflict of interest. 


\section{Appendix A. Effect of Calcination Temperature and Iron Loading}

A range of $\mathrm{Fe}-\mathrm{TiO}_{2}$ photocatalysts were synthesized to screen out the best combination of metal loading and calcination temperature. Different metal loading in the range of $0.01-5 \mathrm{wt} \%$ while calcination temperatures for the activation of $\mathrm{Fe}^{-} \mathrm{TiO}_{2}$ photocatalysts were selected based on the TGA thermograms. Therefore lower $\left(200^{\circ} \mathrm{C}\right)$, moderate $\left(300{ }^{\circ} \mathrm{C}\right)$, and higher $\left(400^{\circ} \mathrm{C}\right)$ temperatures were selected to analyze the effect of calcination. List of photocatalyst synthesized along with performance using iron as a dopant with different metal loading and calcination temperature is shown in following Table A1.

Table A1. Effect of calcination temperatures on RB5 decolorization for different $\mathrm{Fe}-\mathrm{TiO}_{2}$ loadings.

\begin{tabular}{cccc}
\hline \multirow{2}{*}{ Photocatalyst } & \multicolumn{3}{c}{ Calcination Temperature $\left({ }^{\circ} \mathbf{C}\right)$} \\
\cline { 2 - 4 } & $\mathbf{2 0 0}{ }^{\circ} \mathbf{C}$ & $\mathbf{3 0 0}{ }^{\circ} \mathbf{C}$ & $\mathbf{4 0 0}{ }^{\circ} \mathbf{C}$ \\
\hline $0.0 \mathrm{Fe}-\mathrm{TiO}_{2}$ & 40.16 & 47.73 & 28.35 \\
$0.01 \mathrm{Fe}-\mathrm{TiO}_{2}$ & 74.46 & 76.11 & 70.37 \\
$0.05 \mathrm{Fe}-\mathrm{TiO}_{2}$ & 78.64 & 82.31 & 79.45 \\
$0.1 \mathrm{Fe}-\mathrm{TiO}_{2}$ & 86.63 & 91.06 & 88.63 \\
$0.5 \mathrm{Fe}-\mathrm{TiO}_{2}$ & 79.13 & 86.80 & 84.01 \\
$1.0 \mathrm{Fe}-\mathrm{TiO}_{2}$ & 69.53 & 83.39 & 80.72 \\
$5.0 \mathrm{Fe}-\mathrm{TiO}_{2}$ & 61.30 & 79.30 & 75.97 \\
\hline
\end{tabular}

Reaction Conditions: Reaction temperature $22^{\circ} \mathrm{C}$, photocatalyst dose $1 \mathrm{~g} \mathrm{~L}^{-1}, \mathrm{pH} 6.2$, dye conc. $30 \mathrm{mg} \mathrm{L}^{-1}$, illumination $500 \mathrm{w}$ halogen lamp.

Table A1 also explains the effect of iron loading on the decolorization capability of synthesized photocatalysts for RB5 dye. Similar trend was found for iron loading at different calcination temperatures, percent decolorization increased with increasing iron loading but it started decreasing after an optimum loading level. In our case the optimum iron loading was observed to be 0.1 weight percent, where maximum decolorization was found to be 86,91 and 88 percent at 200,300 and $400{ }^{\circ} \mathrm{C}$ calcination temperatures, respectively. Similar results were reported previously, where 100\% RB5 decolorization was obtained for $1.65 \mathrm{Fe}-\mathrm{TiO}_{2}-450$ [29]. When the iron load is high on the photocatalyst, metal oxides are formed and function as charge recombination centres which decrease the photocatalytic activity by the interference with mass transfer, avoiding the charge carrier species to continue the photocatalytic process [70,72]. Another study found that iron spread across the surface of $\mathrm{TiO}_{2}$ which serve as charged species trappers which decrease electron/hole pairs' recombination rate, favouring the formation of a growing number of radical species and improving photocatalytic efficiency [68]. It is also well understood from previous studies that iron loading restrains the increase in grain size and refine the crystallite size, which ultimately increase the photocatalyst performance [73]. It can be concluded that the proposed nanoparticle i.e., $0.1 \mathrm{Fe}-\mathrm{TiO}_{2}-300$ showed better decolorization performance in $60 \mathrm{~min}$, low calcination temperature and low level of dopant when compared with the reported literature.

\section{References}

1. Favero, B.M.; Favero, A.C.; Taffarel, S.R.; Souza, F.S. Evaluation of the efficiency of coagulation/flocculation and Fenton process in reduction of colour, turbidity and COD of a textile effluent. Environ. Technol. 2020, 41, 1580-1589. [CrossRef] [PubMed]

2. Balcik-Canbolat, C.; Sengezer, C.; Sakar, H.; Karagunduz, A.; Keskinler, B. A study on near zero liquid discharge approach for the treatment of reverse osmosis membrane concentrate by electrodialysis. Environ. Technol. 2020, 41, 440-449. [CrossRef]

3. Desa, A.; Dahlan, D.; Misdan, N.; Abu Bakar Sidik, D.; Hairom, N.; Leman, A.; Abdullahi, T.; Harun, Z.; Yusof, N. A Comparative Study of Direct Ultrafiltration Process and Membrane Photocatalytic Reactor System for Textile Wastewater Treatment. Res. J. Chem. Environ. 2020, 24, 5.

4. Shah, J.A.; Butt, T.A.; Mirza, C.R.; Shaikh, A.J.; Khan, M.S.; Arshad, M.; Riaz, N.; Haroon, H.; Gardazi, S.M.H.; Yaqoob, K. Phosphoric Acid Activated Carbon from Melia azedarach Waste Sawdust for Adsorptive Removal of Reactive Orange 16: Equilibrium Modelling and Thermodynamic Analysis. Molecules 2020, 25, 2118. [CrossRef] [PubMed] 
5. Haroon, H.; Shah, J.A.; Khan, M.S.; Alam, T.; Khan, R.; Asad, S.A.; Ali, M.A.; Farooq, G.; Iqbal, M.; Bilal, M. Activated carbon from a specific plant precursor biomass for hazardous $\mathrm{Cr}(\mathrm{VI})$ adsorption and recovery studies in batch and column reactors: Isotherm and kinetic modeling. J. Water Process Eng. 2020, 38, 101577. [CrossRef]

6. Misra, M.; Akansha, K.; Sachan, A.; Sachan, S.G. Removal of Dyes from Industrial Effluents by Application of Combined Biological and Physicochemical Treatment Approaches. In Combined Application of Physico-Chemical E Microbiological Processes for Industrial Effluent Treatment Plant; Springer: Berlin/Heidelberg, Germany, 2020; pp. 365-407.

7. Ijanu, E.; Kamaruddin, M.; Norashiddin, F. Coffee processing wastewater treatment: A critical review on current treatment technologies with a proposed alternative. Appl. Water Sci. 2020, 10, 11. [CrossRef]

8. Riaz, N.; Hassan, M.; Siddique, M.; Mahmood, Q.; Farooq, U.; Sarwar, R.; Khan, M.S. Photocatalytic degradation and kinetic modeling of azo dye using bimetallic photocatalysts: Effect of synthesis and operational parameters. Environ. Sci. Pollut. Res. 2020, 27, 2992-3006. [CrossRef] [PubMed]

9. Khan, M.S.; Kait, C.F.; Mutalib, M.I.A. Photooxidative desulfurization for diesel using Fe/N-TiO 2 photocatalyst. In AIP Conference Proceedings; American Institute of Physics: College Park, MD, USA, 2014; Volume 1621, pp. 10-16.

10. Riaz, N.; Mohamad Azmi, B.-K.; Mohd Shariff, A. Iron doped $\mathrm{TiO}_{2}$ photocatalysts for environmental applications: Fundamentals and progress. In Advanced Materials Research; Trans Tech Publications Ltd.: Freienbach, Switzerland, 2014; Volume 925, pp. 689-693.

11. Cheng, G.; Liu, X.; Song, X.; Chen, X.; Dai, W.; Yuan, R.; Fu, X. Visible-light-driven deep oxidation of $\mathrm{NO}_{\text {over Fe doped TiO }}$ catalyst: Synergic effect of Fe and oxygen vacancies. Appl. Catal. B Environ. 2020, 277, 119196. [CrossRef]

12. Zhang, Y.; Shen, Y.; Gu, F.; Wu, M.; Xie, Y.; Zhang, J. Influence of Fe ions in characteristics and optical properties of mesoporous titanium oxide thin films. Appl. Surf. Sci. 2009, 256, 85-89. [CrossRef]

13. Vijayalakshmi, K.; Jereil, S.D. Influence of Fe catalytic doping on the properties of $\mathrm{TiO}_{2}$ nanoparticles synthesized by microwave method. J. Mater. Sci. Mater. Electron. 2014, 25, 5089-5094. [CrossRef]

14. Soo, C.W.; Juan, J.C.; Lai, C.W.; Hamid, S.B.A.; Yusop, R.M. Fe-doped mesoporous anatase-brookite titania in the solar-lightinduced photodegradation of Reactive Black 5 dye. J. Taiwan Inst. Chem. Eng. 2016, 68, 153-161. [CrossRef]

15. Zhu, J.; Chen, F.; Zhang, J.; Chen, H.; Anpo, M. Fe ${ }^{3+}-\mathrm{TiO}_{2}$ photocatalysts prepared by combining sol-gel method with hydrothermal treatment and their characterization. J. Photochem. Photobiol. A Chem. 2006, 180, 196-204. [CrossRef]

16. Komaraiah, D.; Radha, E.; Kalarikkal, N.; Sivakumar, J.; Ramana Reddy, M.V.; Sayanna, R. Structural, optical and photoluminescence studies of sol-gel synthesized pure and iron doped $\mathrm{TiO}_{2}$ photocatalysts. Ceram. Int. 2019, 45, 25060-25068. [CrossRef]

17. Siti Aida, I.; Abdul Hadi Zainal, A.; Rosniza, H.; Zakiah, K.; Mohamed Nasrul Mohamed, H.; Ainun Rahmahwati, A.; Muhamad Zaini, Y. Effect of Calcination Temperature on (N, Fe) Doped $\mathrm{TiO}_{2}$ Nanoparticles. J. Sci. Technol. 2018, 10, 44-48.

18. Faisal, A.Q.D. Synthesis and characteristics study of TiO 2 nanowires and nanoflowers on FTO/glass and glass substrates via hydrothermal technique. J. Mater. Sci. Mater. Electron. 2015, 26, 317-321.

19. Ranjit, K.T.; Viswanathan, B. Synthesis, characterization and photocatalytic properties of iron-doped $\mathrm{TiO}_{2}$ catalysts. J. Photochem. Photobiol. A Chem. 1997, 108, 79-84. [CrossRef]

20. Lucas, M.S.; Tavares, P.B.; Peres, J.A.; Faria, J.L.; Rocha, M.; Pereira, C.; Freire, C. Photocatalytic degradation of Reactive Black 5 with $\mathrm{TiO}_{2}$-coated magnetic nanoparticles. Catal. Today 2013, 209, 116-121. [CrossRef]

21. Ismael, M. Enhanced photocatalytic hydrogen production and degradation of organic pollutants from Fe (III) doped TiO 2 nanoparticles. J. Environ. Chem. Eng. 2020, 8, 103676. [CrossRef]

22. Ranganayaki, T.; Venkatachalam, M.; Vasuki, T.; Shankar, S. Preparation and characterization of nanocrystalline $\mathrm{TiO}_{2}$ thin films prepared by sol-gel spin-coating method. Int. J. Innov. Res. Sci. Eng. Technol. 2014, 3, 16707-16713.

23. Al-Jawad, S.M.H.; Taha, A.A.; Salim, M.M. Synthesis and characterization of pure and Fe doped TiO 2 thin films for antimicrobial activity. Optik 2017, 142, 42-53. [CrossRef]

24. Hossain, M.A.; Elias, M.; Sarker, D.R.; Diba, Z.R.; Mithun, J.M.; Azad, M.A.K.; Siddiquey, I.A.; Rahman, M.M.; Uddin, J.; Uddin, M.N. Synthesis of Fe- or Ag-doped $\mathrm{TiO}_{2}-\mathrm{MWCNT}$ nanocomposite thin films and their visible-light-induced catalysis of dye degradation and antibacterial activity. Res. Chem. Intermed. 2018, 44, 2667-2683. [CrossRef]

25. Yadav, H.M.; Kolekar, T.V.; Pawar, S.H.; Kim, J.-S. Enhanced photocatalytic inactivation of bacteria on Fe-containing TiO 2 nanoparticles under fluorescent light. J. Mater. Sci. Mater. Med. 2016, 27, 57. [CrossRef]

26. Delekar, S.D.; Yadav, H.M.; Achary, S.N.; Meena, S.S.; Pawar, S.H. Structural refinement and photocatalytic activity of Fe-doped anatase $\mathrm{TiO}_{2}$ nanoparticles. Appl. Surf. Sci. 2012, 263, 536-545. [CrossRef]

27. Wang, S.; Lian, J.S.; Zheng, W.T.; Jiang, Q. Photocatalytic property of Fe doped anatase and rutile $\mathrm{TiO}_{2}$ nanocrystal particles prepared by sol-gel technique. Appl. Surf. Sci. 2012, 263, 260-265. [CrossRef]

28. Subramaniam, M.N.; Goh, P.S.; Lau, W.J.; Ismail, A.F.; Karaman, M. Enhanced visible light photocatalytic degradation of organic pollutants by iron doped titania nanotubes synthesized via facile one-pot hydrothermal. Powder Technol. 2020, 366, 96-106. [CrossRef]

29. Liu, J.; Zhang, Z.; Yang, L.; Zhang, Y.; Deng, S. The degradation of reactive black wastewater by $\mathrm{Fe} / \mathrm{Cu}$ co-doped $\mathrm{TiO}_{2}$. Int. J. Chem. 2011, 3, 87-93. [CrossRef] 
30. Iftikhar, A.; Khan, M.S.; Rashid, U.; Mahmood, Q.; Zafar, H.; Bilal, M.; Riaz, N. Influence of metallic species for efficient photocatalytic water disinfection: Bactericidal mechanism of in vitro results using docking simulation. Env. Sci. Pollut. Res. Int. 2020, 27, 39819-39831. [CrossRef]

31. Lam, S.-M.; Quek, J.-A.; Sin, J.-C. Mechanistic investigation of visible light responsive Ag/ZnO micro/nanoflowers for enhanced photocatalytic performance and antibacterial activity. J. Photochem. Photobiol. A Chem. 2018, 353, 171-184. [CrossRef]

32. Antonelli, D.M.; Ying, J.Y. Synthesis of hexagonally packed mesoporous $\mathrm{TiO}_{2}$ by a modified sol-gel method. Angew. Chem. Int. Ed. Engl. 1995, 34, 2014-2017. [CrossRef]

33. Riaz, N.; Chong, F.K.; Dutta, B.K.; Man, Z.B.; Khan, M.S.; Nurlaela, E. Photodegradation of Orange II under visible light using $\mathrm{Cu}-\mathrm{Ni} / \mathrm{TiO}_{2}$ : Effect of calcination temperature. Chem. Eng. J. 2012, 185, 108-119. [CrossRef]

34. Langford, J.I.; Wilson, A. Scherrer after sixty years: A survey and some new results in the determination of crystallite size. J. Appl. Crystallogr. 1978, 11, 102-113. [CrossRef]

35. Houas, A.; Lachheb, H.; Ksibi, M.; Elaloui, E.; Guillard, C.; Herrmann, J.-M. Photocatalytic degradation pathway of methylene blue in water. Appl. Catal. B Environ. 2001, 31, 145-157. [CrossRef]

36. Khan, M.S.; Shah, J.A.; Arshad, M.; Halim, S.A.; Khan, A.; Shaikh, A.J.; Riaz, N.; Khan, A.J.; Arfan, M.; Shahid, M.; et al. Photocatalytic decolorization and biocidal applications of nonmetal doped $\mathrm{TiO}_{2}$ : Isotherm, kinetic modeling and In Silico molecular docking studies. Molecules 2020, 25, 4468. [CrossRef] [PubMed]

37. Azbar, N.; Yonar, T.; Kestioglu, K. Comparison of various advanced oxidation processes and chemical treatment methods for COD and color removal from a polyester and acetate fiber dyeing effluent. Chemosphere 2004, 55, 35-43. [CrossRef] [PubMed]

38. Šijaković-Vuji, N.; Gotić, M.; Musić, S.; Ivanda, M.; Popović, S. Synthesis and microstructural properties of Fe-TiO 2 nanocrystalline particles obtained by a modified sol-gel method. J. Sol-Gel Sci. Technol. 2004, 30, 5-19. [CrossRef]

39. Ali, T.; Tripathi, P.; Azam, A.; Raza, W.; Ahmed, A.S.; Ahmed, A.; Muneer, M. Photocatalytic performance of Fe-doped TiO 2 nanoparticles under visible-light irradiation. Mater. Res. Express 2017, 4, 015022. [CrossRef]

40. Solano Pizarro, R.A.; Herrera Barros, A.P. Cypermethrin elimination using $\mathrm{Fe}^{-} \mathrm{TiO}_{2}$ nanoparticles supported on coconut palm spathe in a solar flat plate photoreactor. Adv. Compos. Lett. 2020, 29, 1-13. [CrossRef]

41. Abdelhaleem, A.; Chu, W.; Liang, X. Diphenamid degradation via sulfite activation under visible LED using Fe (III) impregnated $\mathrm{N}$-doped $\mathrm{TiO}_{2}$ photocatalyst. Appl. Catal. B Environ. 2019, 244, 823-835. [CrossRef]

42. Riaz, N.; Chong, F.K.; Dutta, B.K.; Man, Z.B.; Khan, M.S.; Nurlaela, E. Effect of calcination temperature on Orange II photocatalytic degradation using $\mathrm{Cu}: \mathrm{Ni} / \mathrm{TiO}_{2}$ under visible light. In Proceedings of the 2011 National Postgraduate Conference, Perak, Malaysia, 19-20 September 2011; pp. 1-5.

43. Devi, L.G.; Anitha, B. Exploration of vectorial charge transfer mechanism in $\mathrm{TiO}_{2} / \mathrm{SrTiO}_{3}$ composite under UV light illumination for the degradation of 4-Nitrophenol: A comparative study with $\mathrm{TiO}_{2}$ and $\mathrm{SrTiO}_{3}$. Surf. Interfaces 2018, 11, 48-56. [CrossRef]

44. Solano, R.A.; Herrera, A.P.; Maestre, D.; Cremades, A. Fe- $\mathrm{TiO}_{2}$ Nanoparticles Synthesized by Green Chemistry for Potential Application in Waste Water Photocatalytic Treatment. J. Nanotechnol. 2019, 2019, 4571848. [CrossRef]

45. Wantala, K.; Laokiat, L.; Khemthong, P.; Grisdanurak, N.; Fukaya, K. Calcination temperature effect on solvothermal Fe-TiO 2 and its performance under visible light irradiation. J. Taiwan Inst. Chem. Eng. 2010, 41, 612-616. [CrossRef]

46. Dahman, Y.; Hoda, Javaheri; Jiafu, Chen; Basel Al-Chikh, Sulaiman. Nanoparticles. In Nanotechnology and Functional Materials for Engineers; Dahman, Y., Ed.; Elsevier: Amsterdam, The Netherlands, 2017; pp. 93-119. [CrossRef]

47. Cheng, X.; Yu, X.; Xing, Z.; Yang, L. Synthesis and characterization of $\mathrm{N}$-doped $\mathrm{TiO}_{2}$ and its enhanced visible-light photocatalytic activity. Arab. J. Chem. 2016, 9, S1706-S1711. [CrossRef]

48. Tauc, J. Optical properties of amorphous semiconductors. In Amorphous and Liquid Semiconductors; Springer: Berlin/Heidelberg, Germany, 1974; pp. 159-220.

49. Almquist, C.B.; Biswas, P. Role of synthesis method and particle size of nanostructured $\mathrm{TiO}_{2}$ on its photoactivity. J. Catal. 2002, 212, 145-156. [CrossRef]

50. Wang, Z.; Cai, W.; Hong, X.; Zhao, X.; Xu, F.; Cai, C. Photocatalytic degradation of phenol in aqueous nitrogen-doped TiO 2 suspensions with various light sources. Appl. Catal. B Environ. 2005, 57, 223-231. [CrossRef]

51. Moradi, V.; Ahmed, F.; Jun, M.B.; Blackburn, A.; Herring, R.A. Acid-treated Fe-doped $\mathrm{TiO}_{2}$ as a high performance photocatalyst used for degradation of phenol under visible light irradiation. J. Environ. Sci. 2019, 83, 183-194. [CrossRef] [PubMed]

52. Ambati, R.; Gogate, P.R. Photocatalytic degradation of Acid Blue 80 using iron doped $\mathrm{TiO}_{2}$ catalyst: Understanding the effect of operating parameters and combinations for synergism. J. Water Process Eng. 2017, 20, 217-225. [CrossRef]

53. Kalantary, R.R.; Dadban Shahamat, Y.; Farzadkia, M.; Esrafili, A.; Asgharnia, H. Photocatalytic degradation and mineralization of diazinon in aqueous solution using nano- $\mathrm{TiO}_{2}$ (Degussa, P25): Kinetic and statistical analysis. Desalination Water Treat. 2015, 55, 555-563. [CrossRef]

54. Kansal, S.K.; Ali, A.H.; Kapoor, S. Photocatalytic decolorization of biebrich scarlet dye in aqueous phase using different nanophotocatalysts. Desalination 2010, 259, 147-155. [CrossRef]

55. Chen, D.; Ray, A.K. Photodegradation kinetics of 4-nitrophenol in $\mathrm{TiO}_{2}$ suspension. Water Res. 1998, 32, 3223-3234. [CrossRef]

56. Eslami, A.; Amini, M.M.; Yazdanbakhsh, A.R.; Mohseni-Bandpei, A.; Safari, A.A.; Asadi, A. N, S co-doped TiO 2 nanoparticles and nanosheets in simulated solar light for photocatalytic degradation of non-steroidal anti-inflammatory drugs in water: A comparative study. J. Chem. Technol. Biotechnol. 2016, 91, 2693-2704. [CrossRef] 
57. Tabasideh, S.; Maleki, A.; Shahmoradi, B.; Ghahremani, E.; McKay, G. Sonophotocatalytic degradation of diazinon in aqueous solution using iron-doped $\mathrm{TiO}_{2}$ nanoparticles. Sep. Purif. Technol. 2017, 189, 186-192. [CrossRef]

58. Isari, A.A.; Payan, A.; Fattahi, M.; Jorfi, S.; Kakavandi, B. Photocatalytic degradation of rhodamine B and real textile wastewater using $\mathrm{Fe}$-doped $\mathrm{TiO}_{2}$ anchored on reduced graphene oxide $\left(\mathrm{Fe}-\mathrm{TiO}_{2} / \mathrm{rGO}\right)$ : Characterization and feasibility, mechanism and pathway studies. Appl. Surf. Sci. 2018, 462, 549-564. [CrossRef]

59. Gupta, V.K.; Jain, R.; Mittal, A.; Saleh, T.A.; Nayak, A.; Agarwal, S.; Sikarwar, S. Photo-catalytic degradation of toxic dye amaranth on $\mathrm{TiO}_{2} / \mathrm{UV}$ in aqueous suspensions. Mater. Sci. Eng. C 2012, 32, 12-17. [CrossRef] [PubMed]

60. Gar Alalm, M.; Tawfik, A.; Ookawara, S. Comparison of solar $\mathrm{TiO}_{2}$ photocatalysis and solar photo-Fenton for treatment of pesticides industry wastewater: Operational conditions, kinetics, and costs. J. Water Process Eng. 2015, 8, 55-63. [CrossRef]

61. Çınar, S.; Kaynar, Ü.H.; Aydemir, T.; Çam Kaynar, S.; Ayvacıklı, M. An efficient removal of RB5 from aqueous solution by adsorption onto nano-ZnO/Chitosan composite beads. Int. J. Biol. Macromol. 2017, 96, 459-465. [CrossRef]

62. Shaheed, M.A.; Hussein, F.H. Adsorption of Reactive Black 5 on Synthesized Titanium Dioxide Nanoparticles: Equilibrium Isotherm and Kinetic Studies. J. Nanomater. 2014, 2014, 198561. [CrossRef]

63. Gupta, V.K.; Eren, T.; Atar, N.; Yola, M.L.; Parlak, C.; Karimi-Maleh, H. CoFe ${ }_{2} \mathrm{O}_{4} @ \mathrm{TiO}_{2}$ decorated reduced graphene oxide nanocomposite for photocatalytic degradation of chlorpyrifos. J. Mol. Liq. 2015, 208, 122-129. [CrossRef]

64. Ghasemi, Z.; Seif, A.; Ahmadi, T.S.; Zargar, B.; Rashidi, F.; Rouzbahani, G.M. Thermodynamic and kinetic studies for the adsorption of $\mathrm{Hg}(\mathrm{II})$ by nano- $\mathrm{TiO}_{2}$ from aqueous solution. Adv. Powder Technol. 2012, 23, 148-156. [CrossRef]

65. Šegota, S.; Ćurković, L.; Ljubas, D.; Svetličić, V.; Houra, I.F.; Tomašić, N. Synthesis, characterization and photocatalytic properties of sol-gel $\mathrm{TiO}_{2}$ films. Ceram. Int. 2011, 37, 1153-1160. [CrossRef]

66. Jawad, A.H.; Mubarak, N.S.A.; Ishak, M.A.M.; Ismail, K.; Nawawi, W.I. Kinetics of photocatalytic decolourization of cationic dye using porous $\mathrm{TiO}_{2}$ film. J. Taibah Univ. Sci. 2016, 10, 352-362. [CrossRef]

67. Kumar, P.S.S.; Sivakumar, R.; Anandan, S.; Madhavan, J.; Maruthamuthu, P.; Ashokkumar, M. Photocatalytic degradation of Acid Red 88 using $\mathrm{Au}-\mathrm{TiO}_{2}$ nanoparticles in aqueous solutions. Water Res. 2008, 42, 4878-4884. [CrossRef]

68. Rodríguez, P.A.O.; Pecchi, G.A.; Casuscelli, S.G.; Elías, V.R.; Eimer, G.A. A simple synthesis way to obtain iron-doped TiO 2 nanoparticles as photocatalytic surfaces. Chem. Phys. Lett. 2019, 732, 136643. [CrossRef]

69. Kumar, K.V.; Porkodi, K.; Rocha, F. Langmuir-Hinshelwood kinetics - A theoretical study. Catal. Commun. 2008, 9, 82-84. [CrossRef]

70. Riaz, N.; Kait, C.F.; Man, Z.; Dutta, B.K.; Ramli, R.M.; Khan, M.S. Visible light photodegradation of azo dye by $\mathrm{Cu} / \mathrm{TiO}_{2}$. Adv. Mater. Res. 2014, 917, 151-159. [CrossRef]

71. Lin, L.; Wang, H.; Luo, H.; Xu, P. Enhanced photocatalysis using side-glowing optical fibers coated with Fe-doped TiO 2 nanocomposite thin films. J. Photochem. Photobiol. A Chem. 2015, 307-308, 88-98. [CrossRef]

72. Lin, C.J.; Liou, Y.H.; Zhang, Y.; Chen, C.L.; Dong, C.-L.; Chen, S.-Y.; Stucky, G.D. Mesoporous Fe-doped TiO 2 sub-microspheres with enhanced photocatalytic activity under visible light illumination. Appl. Catal. B Environ. 2012, 127, 175-181. [CrossRef]

73. Ambati, R.; Gogate, P.R. Ultrasound assisted synthesis of iron doped $\mathrm{TiO}_{2}$ catalyst. Ultrason. Sonochemistry 2018, 40, 91-100. [CrossRef] 